\title{
Natural and Semi-Synthetic Pseudoguaianolides as Inhibitors of NF-кB
}

\author{
Rodrigo Villagomez ${ }^{1,2}$, Juan Antonio Collado³, Eduardo Muñoz ${ }^{3}$, Giovanna Almanza², \\ Olov Sterner ${ }^{*}$ \\ ${ }^{1}$ Center for Analysis and Synthesis, Lund University, Lund, Sweden \\ ${ }^{2}$ Laboratorio de Bioorganica, Instituto de Investigaciones Químicas, Universidad Mayor de San Andrés, \\ La Paz, Bolivia \\ ${ }^{3}$ Instituto Maimónides de Investigación Biomédica de Córdoba (IMIBIC), Departamento de Biología Celular, \\ Fisiología e Inmunología, Universidad de Córdoba, Córdoba, Spain \\ Email: $\underline{\text { Olov.Sterner@chem.lu.se }}$
}

Received 8 June 2014; revised 24 July 2014; accepted 9 August 2014

Copyright (C) 2014 by authors and Scientific Research Publishing Inc.

This work is licensed under the Creative Commons Attribution International License (CC BY).

http://creativecommons.org/licenses/by/4.0/

(c) (i) Open Access

\section{Abstract}

Damsin (1) is a natural pseudoguaianolide sesquiterpene that inhibits NF- $\kappa B$, a protein complex that controls the transcription of DNA in mammalian cells, and has a potential for standing model for the development of new anti-cancer lead structures. In order to do a preliminary structure-activity study and improve the anti-cancer activity, fourteen derivatives and analogs were prepared and evaluated. These were chosen to represent both structural diversity and structural novelty. The importance of $\alpha$ methylene- $\gamma$-lactone moiety for the anti-cancer activity was confirmed, even though other features in the scaffold were shown to be important for the activity. In some cases a new substitution negatively affected the initial activity, however, two analogues, indolo [3,2-c]-4desoxydamsin (5) and ambrosin (6), were found to be more potent.

\section{Keywords}

Damsin, $\alpha$ Methylene- $\gamma$-Lactone Sesquiterpenoids, Anti-Cancer Activity

\section{Introduction}

NF-kB, nuclear factor kappa-light-chain-enhancer of activated B cells, is a family of protein complexes that control the transcription of DNA as transcription factors. They are involved in the cellular responses to various stimuli, an important part of the immune system and responsible for cytokine production and cell survival. Poor

${ }^{*}$ Corresponding author.

How to cite this paper: Villagomez, R., Collado, J.A., Muñoz, E., Almanza, G. and Sterner, O. (2014) Natural and SemiSynthetic Pseudoguaianolides as Inhibitors of NF-kB. J. Biomedical Science and Engineering, 7, 833-847. 
regulation of NF- $\kappa B$ is linked to several serious conditions, including cancer. The NF- $\kappa B$ complexes include the subunits RelA (p65), NF-kB1 (p50; p105), NF-kB2 (p52; p100), c-Rel and RelB. The amino-terminal Rel-homology domain (RHD) is conserved within the family, containing the subdomains for dimerization, nuclear localization and DNA-binding. Therefore, homo-and heterodimers between these proteins can be found in vivo, except for RelB, which just forms heterodimers. A dimer is normally associated with the inhibitory protein IкB, and the complex (NF- $\mathrm{kB}-\mathrm{I} \kappa \mathrm{B}$ ) remains inactive in the cytoplasm. A broad number of stimuli are responsible for the activation of such complexes, e.g. pathogens, stress signals and pro-inflammatory cytokines, by activating

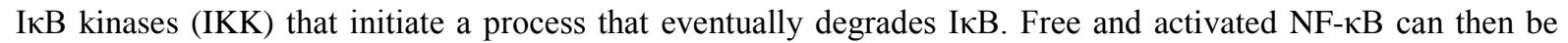
translocated into the nucleus and start the transcription of target genes. The most well-known heterodimer, and present in most mammalian cells, is RelA/p50 [1]-[3]. The main biological functions of NF-kB are the activation of immune response and inflammation via the expression of genes encoding for cytokines, cytokine receptors, and cell-adhesion molecules [1].

In recent years, a deeper understanding of the NF- $\mathrm{KB}$ pathway and its role in inflammatory processes has been established, creating a molecular link between the chronic inflammatory diseases and cancer [4] [5]. Specifically, this transcription factor has been shown to be crucial in oncogenesis and tumor progression, inhibiting apoptosis by transcribing genes for anti-apoptotic proteins or suppressing genes for apoptotic proteins. In a state of constant activation of NF- $\mathrm{kB}$ malignancies may progress even if apoptosis is induced by anti-cancer treatments, leading to chemoresistance [6]. For these reasons, the NF- $\mathrm{BB}$ family is considered to be an interesting target for the development of new anti-cancer drugs [7]-[9], although it should be noted that pro-apoptotic and tumor suppression functions of NF- $k B$ have been reported in some cancer cell lines [10]-[15]. Nevertheless, new inhibitors of NF- $\mathrm{KB}$ are required in order to study and understand the following steps in the signal transduction: a) the blocking of the binding of NF- $\mathrm{KB}$ to DNA; $b$ ) the inhibition of the nuclear import system to prevent NF- $\mathrm{kB}$ from

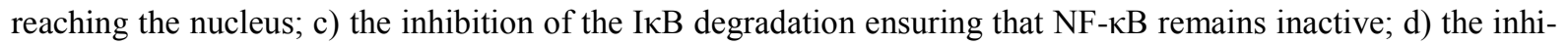
bition of the IKK kinases that initiate the degradation of IאB [16].

Sesquiterpenes with an $\alpha$-methylene- $\gamma$-lactone moiety (e.g. damsin (1), see Scheme 1) constitute a class of natural products with potential as anti-cancer agentsby inhibiting NF- $\mathrm{BB}$ [17]-[21]. Structure-activity relationship studies have demonstrated the importance of the rigid skeleton of pseudoguaianes and/or guaianes with an $\alpha$-methylene- $\gamma$-lactone moiety, as it appears to contribute significantly to both the anti-cancer activity and the NF-KB inhibition [22] [23]. The critical property of these compounds is the ability of the $\alpha$-methylene- $\gamma$-lactones to react as Michael acceptors with thiol groups of cysteines in proteins, modifying the protein covalently [17] [19] [21] [22] [24]-[26]. The reaction of the thiol group ofcysteine-38 in RelA with a Michael acceptor is considered to be the mechanism by which the $\alpha$-methylene- $\gamma$-lactone sesquiterpenes prevent the binding of NF- $\kappa \mathrm{B}$ to DNA. This cysteine is considered crucial for the interaction between NF- $\mathrm{BB}$ and DNA, association with the coactivator RPS3 and antiapoptotic gene expression [27]. The importance of this cysteine residue was also demonstrated by studying mutants of RelA/NF- $\mathrm{kB}$ and measuring their ability to bind to DNA in the absence or presence of $\alpha$-methylene- $\gamma$-lactone sesquiterpenes, showing that this site is affected by this class of natural products [28]-[30].

We have focused our interest on damsin (1), a pseudoguaiane sesquiterpene that can be isolated in large amounts from the plant Ambrosia arborescens Mill. [31]. This natural product is cytotoxic towards Hep-2 cells (epidermoid carcinoma of larynx) [32] and Eagle's KB cells (nasopharynx carcinoma) [33]. In addition, antiproliferative activity was reported in U937 cells (monocytic leukaemia), Jurkat cells (leukaemia T) and Molt 4 cells (acute lymphoblastic leukaemia) [34]. Recently we reported the antiproliferative activity of damsin (1) towards Caco-2 cells (epithelial colorectal adenocarcinoma) and its inhibitory effect on NF-kB and STAT3 (a signal transducer and activator of transcription) [35]. In an effort to prepare new derivatives at least retaining the NF-kB inhibitory capacity, a broad range of chemical transformations were carried out with damsin (1). As $\mathbf{1}$ is chiral, all derivatives obtained from it (see Scheme 1) are consequently pure enantiomers with the absolute configuration as shown. The transformations were partly inspired by the reports from the 1960s, when the structure elucidation of sesquiterpene lactones was based on functional group interconversions [36] [37]. In the later years, the derivatisation studies have focused on the improvement of their biological activities, such as cytotoxicity [38] [39], and the development of pro-drugs as anticancer agents [40] and anti-malarial [41]. Such studies usually only utilized specific chemical reactions, but the aim of this study was to use a broad scope of reactions in order to generate novel structures that are not found in plants. 

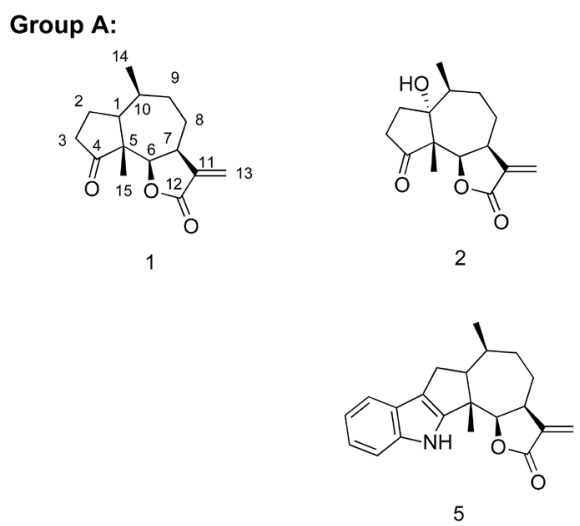

$\mathrm{HO}$<smiles>C=C1C(=O)O[C@H]2[C@@H]1CC[C@@H](C)[C@H]1C[C@@H](C)C(=O)[C@]21C</smiles>

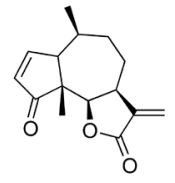

Group B:

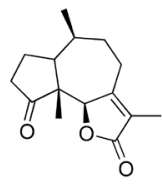

7

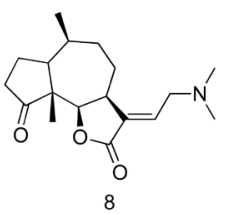

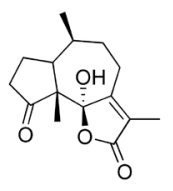

9

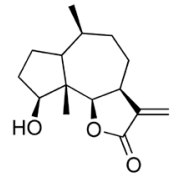

4

Group C:

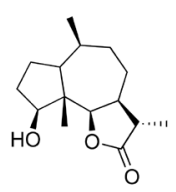

11

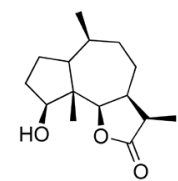

12

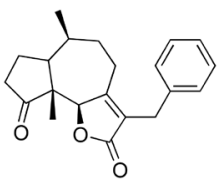

10<smiles>CC1(O)CCC2C(C(=O)O)OC(=O)C23C(=O)CCC13C</smiles>

14

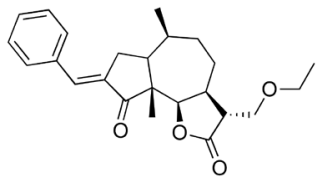

13

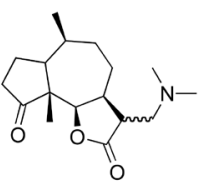

15

Scheme 1. Sesquiterpenes with an $\alpha$-methylene- $\gamma$-lactone moiety.

\section{Results}

Damsin (1) and coronopilin (2) are known pseudoguaiane sesquitepenes that can be isolated from Ambrosia arborescens Mill. [34] [36]. As the isolation of $\mathbf{1}$ in larger amounts was achievable, it was selected as the starting material for all the chemical modifications. Our ambition was not only to modify the Michael acceptor moiety and consequently the reactivity, but also to introduce new groups into the pseudoguaiane skeleton in order to investigate the effect of non-covalent interactions. The compounds prepared can be divided in three categories (Scheme 1): Group A, compounds retaining the $\alpha$-methylene- $\gamma$-lactone moiety; Group B, compounds with a modified Michael acceptor in the $\gamma$-lactone moiety and Group C, compounds lacking a carbon-carbon double bond in the $\gamma$-lactone ring.

Group A. New hydrogen donors/acceptors in $\mathbf{1}$ were introduced in compounds $\mathbf{3}$ and $\mathbf{4}$. A Rubottom oxidation provided 3 that is hydroxylated in position 3 (Scheme 1) [42], while a selective reduction of the keto function through a Luche reduction with $\mathrm{NaBH}_{4}$ in presence of $\mathrm{CeCl}_{3}$ afforded 4 [43]. A Fischer indole synthesis with phenylhydrazine gave 5 that has a planar and rigid structure. To avoid competitive reactions of the hydrazine with the $\alpha$ methylene- $\gamma$-lactone moiety, the thiophenoxide-protected adduct (17) was used as starting material (Scheme 2(a)). The molecule was deprotected by a selective oxidation of the thioether to a sulfoxide with $m$-CPBA at $-20^{\circ} \mathrm{C}$, followed by a thermal elimination. Ambrosin (6), a natural product, was prepared via a Saegusa-Ito oxidation [42]. 6 is unique in this investigation by containing a second Michael acceptor function. 

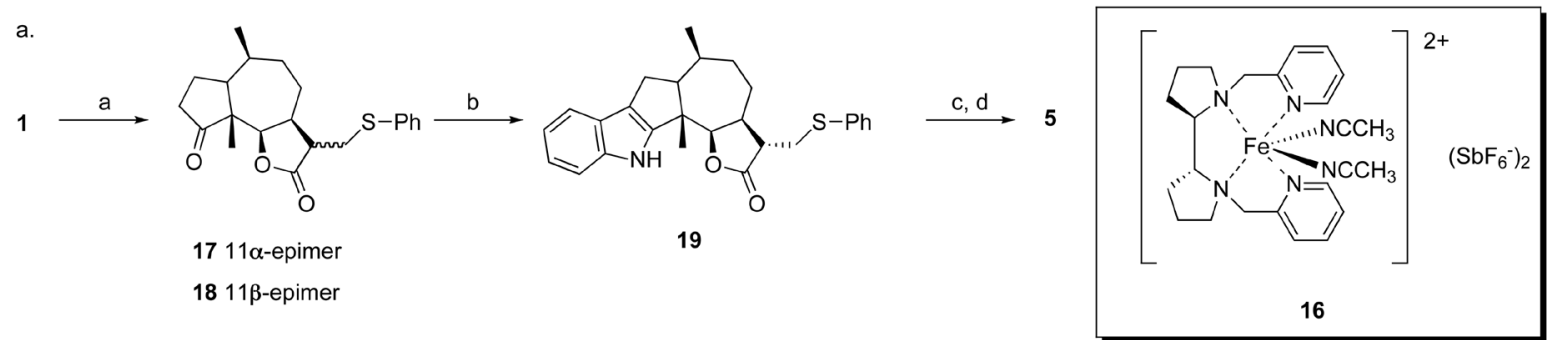

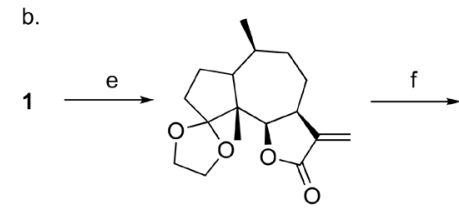

20

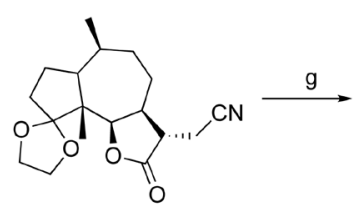

21

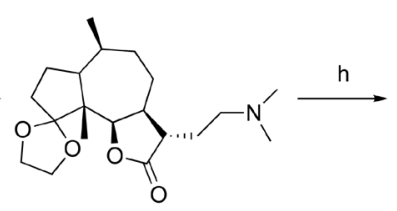

22

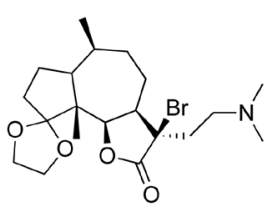

23<smiles>CC(C)C12CCC3C4(OCCO4)[C@@H]4OC(=O)/C(=C\CN(C)C)C4CCC(C)C31OC2</smiles>

24

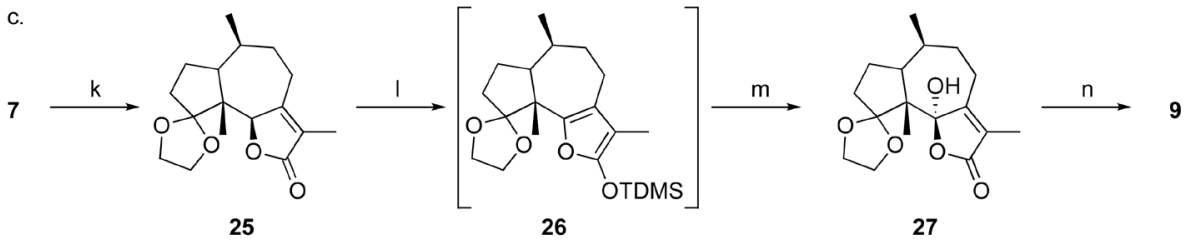

Scheme 2. a. PhSNa/EtOH; b. $\mathrm{H}_{2} \mathrm{NNHPh} / \mathrm{AcOH}$; c. m-CPBA /DCM; d. PhMe, reflux; e. $\left(\mathrm{CH}_{2} \mathrm{OH}\right)_{2},\left(\mathrm{CH}_{3} \mathrm{O}\right)_{3} \mathrm{CH} / 10 \%$ TsOH, DCM; f. ACH, NaCN/DMSO; g. $\mathrm{H}_{2} / \mathrm{Pd}-\mathrm{C} / \mathrm{Me}_{2} \mathrm{NH}$, EtOH; h. TMSOTf, TEA /DCM then PTAB, $0^{\circ} \mathrm{C}$; i. TBAF/THF; j. $\mathrm{HCl} / \mathrm{MeOH}$; k. $\left(\mathrm{CH}_{2} \mathrm{OH}\right)_{2}$, $\left(\mathrm{CH}_{3} \mathrm{O}\right)_{3} \mathrm{CH} / 10 \%$ p-TsOH, DCM; l. TBDMSOTf, TEA/DCM; c. m-CPBA/DCM; n. HCl/ $\mathrm{MeOH}$.

Group B. The isomerization of $\mathbf{1}$ to $\mathbf{7}$ was achieved by treatment with $\mathrm{RhCl}_{3}$ [42], providing a derivative that still is a Michael acceptor but less available for nucleophilic attack and consequently less reactive [40]. 8 was designed to facilitate a Michael addition by providing an intramolecular basic catalysis for an incoming thiol [44]. Several strategies towards 8 were investigated, including metathesis and a Wittig olefination reaction, but the procedure that eventually succeeded (see Scheme 2(b)) starts with a Michael addition of a cyanide ion to the acetal $\mathbf{2 0}$ to give the nitrile $\mathbf{2 1}$. After the reduction of $\mathbf{2 1}$ to the tertiary amine $\mathbf{2 2}$ and the oxidation of the lactone ring of 22 via the bromine 23 to the olefine 24. Finally, 8 was obtained by the hydrolysis of the acetal protection group. Compound $\mathbf{9}$ was prepared from 7 by a procedure similar to the Rubotton oxidation [45]. Firstly, 7 was protected as the acetal 25, which wasoxidized to $\mathbf{2 7}$ via the 2-hydroxyfuran silylether $\mathbf{2 6}$ (not isolated), and finally deprotected by hydrolysis to yield 9 (Scheme 2(c)). Compound 10 was prepared from 1 by a Heck coupling reaction, following procedures reported for $\alpha$-methylene- $\gamma$-lactones [46] [47]. However, the isomerization could not be avoided, yielding the endocyclic $\alpha, \beta$-unsaturated- $\gamma$-lactone $\mathbf{1 0 .}$

Group $C$. Even though it has been stated that the absence of the $\alpha$-methylene- $\gamma$-lactone moiety renders this class of terpenes inactive as inhibitors of NF- $\mathrm{B}$ [29], we wanted to include also such compounds in this investigation. The reduction of the $\alpha$-methylene- $\gamma$-lactone of $\mathbf{1}$ with $\mathrm{NaBH}_{4}$ gave the two epimers 11 and 12 [42]. The Claisen-Schmidt condensation of 1 with benzaldehyde in ethanol gave 13 [48]. The hydroxylated compound 14 was prepared following an iterative procedure [49] with the hydrogen peroxide and catalyst 16 (Scheme 2). Although this catalyst hydroxylated the desired tertiary position, the epoxidation of the double bond was unavoidable. Finally, the reaction of $\mathbf{1}$ with dimethyl amine in ethanol yielded the amine adduct 15 (as an epimeric 
mixture 3:1 11 $\alpha: 11 \beta$ ) [50], for evaluation of its possible usefulness as a pro-drug.

The configuration of the products and intermediates was determined by comparing the ${ }^{1} \mathrm{H}$ NMR coupling constants and correlations observed in the NOESY spectra, with computational models. The conformational search was carried out using the MMFFs force field and the low energy conformers were optimized using B3LYP/6-31G** basis set. In several cases a second order system was resolved in order to determine the coupling constants, and this was done by approximation using spin simulation. For compound 4, for example, the coupling constants and atomic distances of the $4 \beta$-hydroxyl group were experimentally and computationally correlated as follows. While the experimental coupling constants of $\mathrm{H}-4 \alpha$ with $\mathrm{H}-3 \alpha$ and $\mathrm{H}-3 \beta$ both are $9.0 \mathrm{~Hz}$, the calculated coupling constants were $8.0 \mathrm{~Hz}$ for $\mathrm{H}-3 \alpha$ and $8.1 \mathrm{~Hz}$ for $\mathrm{H}-3 \beta$. In addition, a NOESY correlations was observed from $\mathrm{H}-4 \alpha$ toH-1, corresponding with the calculated distance (2.40 $\AA$ ), as well as to H-6 (calculated distance $2.26 \AA$ ). The chiral centers as well as the double bond configurations were assigned in the corresponding way for all the derivatives. The structural elucidation of 3,11 and 12 has previously been reported by us [42].

The coupling constants and atomic distances of each compound with a new chiral center are experimentally and computationally consistent as follows:

Compound 9. A NOE correlation was observed between $\mathrm{OH}-6$ and H-1, corresponding with the calculated distance of $3.04 \AA$.

Compound 13. The configuration of C-11 was assigned considering the experimental coupling constant of $\mathrm{H}-11 \beta$ with $\mathrm{H}-7 \alpha(7.2 \mathrm{~Hz})$, compared with the calculated coupling constant $(11.9 \mathrm{~Hz})$. In addition, NOESY correlations were observed between $\mathrm{H}-11 \beta$ and $\mathrm{H}_{3}-15, \mathrm{H}-8 \alpha, \mathrm{H}-8 \beta$ and $\mathrm{H}-9 \beta$ corresponding to the calculated interatomic distances 2.36, 3.01, 3.86 and 2.16 $\AA$, respectively. NOESY correlations between $\mathrm{H}_{2}-13$ to-OCH${ }_{2} \underline{C H}_{3}$ (weak), $\mathrm{H}-7,-\mathrm{OCH}_{2} \mathrm{CH}_{3}$ and $\mathrm{H}-6$ correspond to the interatomic distances 4.60, 2.70, 2.40 and $2.54 \AA$, respectively. A second order system (ABM) was resolved for $\mathrm{H}-13 \mathrm{a}$ and $\mathrm{H}-13 \mathrm{~b}$, to discriminate their coupling constants with $\mathrm{H}-11 \beta$. The error is small enough to confirm the proposed stereochemistry, even though the contribution of more than one conformer could explain the divergence. In addition the $E$ isomerism of the 3-phenylethenyl, was confirmed trough NOE correlations of H-2' with H-2a and H-2b (2.224 $\AA$ and 2.449 A, respectively).

Compound 15. The relative amounts of the two diastereomers in the epimeric mixture obtained was made using the integral of H-6 for each epimer. The complete assignation was done by a careful analysis of the 2D spectra. The configuration of C-11 in the two epimers was determined by the NOESY correlation observed between $\mathrm{H}-11$ and $_{3}-15$ in the spectrum of the major epimer $(11 \beta$, 13-dihydro-13-( $N, N$-dimethylamino) damsin)),and the correlation between H-11 and H-6 for the minor epimer (11 $\alpha$, 13-dihydro-13-( $N$, $N$-dimethylamino) damsin.

Compound 17. The configuration of C-11 in 17 was suggested by the experimental coupling constant between $\mathrm{H}-11 \beta$ and $\mathrm{H}-7(7.7 \mathrm{~Hz})$ compared with the calculated coupling constant $(11.4 \mathrm{~Hz})$. This was confirmed by the NOESY correlations between $\mathrm{H}-11 \beta$ and $\mathrm{H}-8 \beta$ (weak), $\mathrm{H}-9 \beta$ and $\mathrm{H}_{3}-15$ corresponding to the interatomic distances 3.01, 2.23 and $2.37 \AA$, respectively.

Compound 18. The configuration of C-11 in 17 was suggested by the experimental coupling constant between $\mathrm{H}-11 \alpha$ and $\mathrm{H}-7(6.0 \mathrm{~Hz})$ compared with the calculated coupling constant $(6.4 \mathrm{~Hz})$. A second order system (AMNX) was resolved for H-11 $\alpha, \mathrm{H}-7, \mathrm{H}-13 \mathrm{a}$ and $\mathrm{H}-13 \mathrm{~b}$, in order to determine their coupling constants and chemical shifts. In addition, a NOESY correlation was observed between $\mathrm{H}-11 \alpha$ and H-6 corresponding to the interatomic distance of $2.51 \AA$.

Compound 22. NOESY correlations were observed between $\mathrm{H}-11 \beta$ and $\mathrm{H}-8 \beta$ as well as $\mathrm{H}_{3}-15$, corresponding with the calculated distance of 2.42 and $2.44 \AA$, respectively.

\section{NF-אB Inhibition and Structure Activity Relationship}

To analyze the NF- $\kappa$ B inhibitory activity of the synthesized compounds we used the stably transfected cell line 5.1, a lymphoid T cell line in which the HIV-1 LTR is activated by TNF- $\alpha$ through an NF- $\kappa$ B dependent mechanism [51]. The HIV-1 LTR promoter contains two $\kappa \mathrm{B}$ sites that are critically required to respond to TNF $\alpha$, and it is well known that deletion of the two $\kappa \mathrm{B}$ sites in the LTR promoter abolishes completely the response to TNF $\alpha$. Thus, 5.1 cells represent an excellent cellular model for the screening of anti-NF- $\kappa B$ compounds. We have previously found that dasmin (1) and coronofilin (2) possess anti-NF- $\kappa$ B activity, with IC $_{50}$ values of 7.2 and $10.1 \mu \mathrm{M}$ respectively [35]. As shown in Table 1, two compounds from group A (5 and 6) have a lower $\mathrm{IC}_{50}$ value compared to $\mathbf{1}$, suggesting that indolic system slightly favors the ability of the compound to interact 
Table 1. Inhibitory activity ( $\mathrm{IC}_{50}$ ) on TNF $\alpha$-induced NF-kB activation. The results represent the mean of three independent experiments and the SD was less than $10 \%$.

\begin{tabular}{cc}
\hline Compound & IC50 $(\mu \mathrm{M})$ \\
\hline 3 & 76 \\
4 & 29 \\
5 & 6.0 \\
6 & 0.50 \\
7 & $>100$ \\
8 & $>100$ \\
9 & 36 \\
10 & 76 \\
11 & $>100$ \\
12 & $>100$ \\
13 & 34 \\
14 & $>100$ \\
15 & 31 \\
\hline
\end{tabular}

with the protein. Compound $\mathbf{6}$ is the most active, probably due the presence of two $\alpha, \beta$-unsaturated carbonyl moieties that increase the alkylating capacity of the product, and this has been noted previously [18] [23] [52]. On the other hand, compounds $\mathbf{2}, \mathbf{3}$ and $\mathbf{4}$ still possess theoriginal $\alpha$-methylene- $\gamma$-lactone but are less potent (especially $\mathbf{3}$ and $\mathbf{4}$ ) compared to $\mathbf{1}$. These results strongly indicate that a number of intermolecular interactions between the compound assayed and the protein it affects modulate their effects, and that a more systematic QSAR study to understand such interactions in detail is motivated.

The compounds in group B possess a modified $\alpha$-methylene- $\gamma$-lactone moiety. Compound $\mathbf{7}$ is inactive at the maximal concentration tested, which could be explained by the lower reactivityof the endocyclic $\alpha$, $\beta$-unsaturated- $\gamma$-lactone moiety and its inability to form stable adducts with thiols [53]. However, compound 8 is also inactive although it was designed to provide support for a thiol attacking C-13. Possibly the steric hindrance posed by the C-13 substituent prevents an attack. Compound $\mathbf{9}$ is an interesting exception with an intermediate activity, possibly caused by a hydrolysis of the hemi-acetal lactonic ring forming a 1,4-enedione with a higher reactivity. Compound $\mathbf{1 0}$ is less potent, but the comparison with $\mathbf{7}$ and indicates that the aromatic group in position 13 slightly enhance the ability of the compound with the protein.

The compounds of group $C$ as $\mathbf{1 1}$ and $\mathbf{1 2}$ are inactive as was predictable, confirming the crucial role of the $\alpha$-methylene- $\gamma$-lactone moiety for the inhibition of NF-кB [23]. The inactivity of compound $\mathbf{1 4}$ demonstrate that other electrophilic groups, such as an epoxide, in positions 11, 13 can not replace the $\alpha$-methylene- $\gamma$-lactone moiety, even though the position is the same. Compounds $\mathbf{1 3}$ and $\mathbf{1 5}$ are weakly active, this could be explained ifthe Michael addition of etoxide and dimethyl amine to the $\alpha$-methylene- $\gamma$-lactone moiety is reversible but this was not further investigated. Amines like 15 are classical pro-drugsof sesquiterpene lactones [18] [40] [50], although $\mathbf{1 5}$ is considerably less activecompared todamsin (1) in this study.

\section{Conclusion}

In total, fourteen derivatives were prepared, characterized and assayed. Several $(7, \mathbf{8}, \mathbf{1 1}, 12$ and 14) were inactive at the tested concentrations, confirming the importance of the $\alpha$-methylene- $\gamma$-lactone moiety for the activity. Nevertheless, compound $\mathbf{1 0}$ is slightly active, suggesting that also endocyclic Michael acceptors may be active and that an aromatic group in position 13 can be important. Also, compound $\mathbf{9}$ was unexpectedly active, probably because the hemi-acetal can be hydrolyzed to a more reactive 1,4-enedione. The compounds $\mathbf{2}, \mathbf{3}$ and $\mathbf{4}$ are 
somewhat surprisingly less active compared to $\mathbf{1}$, indicating that hydroxyl groups on positions 1 , 3 or 4 , respectively, have a negative effect on the ability of the sesquiterpene to interact with the protein. For compound 15, the ability to regenerate the $\alpha$-methylene- $\gamma$-lactone moiety during the performance of the assay is the probable reason for its modest activity, amine adducts (15) have previously been demonstrated to possess such a reversibility [50]. This is not the case for ethers, e.g. 13, so there may be another reason for its modest activity. Finally, compounds $\mathbf{5}$ and $\mathbf{6}$ are more potent compared to 1. This was expected for $\mathbf{6}$ as it possesses two Michael acceptors, but unexpected for $\mathbf{5}$. Possible explainations are that the indol system imposes a steric strain on the molecule, including the $\alpha$-methylene- $\gamma$-lactone moiety, which could be relieved if C-11 no longer is part of an unsaturation. Alternatively the indole may be involved in some specific interaction with the molecular environment of the reacting cysteine, favoring the position of the $\alpha$-methylene- $\gamma$-lactone moiety in the right place. The need for a more systematic investigation is evident.

\section{Experimental}

a) Chemistry

\section{General}

All other chemicals were obtained from commercial suppliers of analytical grade. High Resolution Mass Spectrometry (HMRS) Electrospray Ionization (ESI) spectra were recorded with a Micromass Quadrupole-time of Flight (Q-TOF) Micro spectrometer. Nuclear Magnetic Resonance (NMR) spectra (in $\mathrm{CDCl}_{3}$ ) were recorded with a Bruker DRX at $400 \mathrm{Mhz}\left({ }^{1} \mathrm{H}\right)$ and at $100 \mathrm{MHz}\left({ }^{13} \mathrm{C}\right)$. Chemical shifts are given in ppm relative to the residual $\mathrm{CHCl}_{3}$ in $\mathrm{CDCl}_{3}\left(7.25 \mathrm{ppm}{ }^{1} \mathrm{H}\right.$ and $\left.77.00 \mathrm{ppm}{ }^{13} \mathrm{C}\right)$. All flash chromatography was performed with $60 \AA$ 30 - $75 \mu \mathrm{m}$ silica gel. Thin Layer Chromatography (TLC) analyses were come out on silica Gel 60 F254 (Merck, Darmstadt, Germany) plates.

4/ -hydroxy-4-deoxydamsin (4). To a solution of $\mathbf{1}(100 \mathrm{mg}, 0.4027 \mathrm{mmol})$ and $\mathrm{CeCl}_{3} \cdot 7 \mathrm{H}_{2} \mathrm{O}(150.0 \mathrm{mg}$, $0.4027 \mathrm{mmol})$ in $\mathrm{MeOH}(2.5 \mathrm{~mL})$, was added $\mathrm{NaBH}_{4}(15.2 \mathrm{mg}, 0.4027 \mathrm{mmol})$ in one portion. The reaction mixture was stirred at room temperature for $40 \mathrm{~min}$ and then quenched with a $10 \% \mathrm{HCl}$ solution $(1 \mathrm{~mL})$. The mixture was neutralized with $\mathrm{NaHCO}_{3}$ sat. $(\mathrm{pH}=7)$ and the aqueous mixture was extracted with $\mathrm{DCM}(4 \times 10$ $\mathrm{mL}$ ). The combined organic layers were dried with $\mathrm{Na}_{2} \mathrm{SO}_{4}$ and concentrated in vacuo to give the crude product, which was purified by silicagel flash chromatography (30\% EtOAc: Pet. Et.40-60) to provide the product 4 (77.2 mg, 76\%). $[\alpha]_{\mathbf{D}}{ }^{20}$ : $-39.9\left(c 1.00, \mathrm{CH}_{2} \mathrm{Cl}_{2}\right)$; IR (film) = 3468, 2960, 2920, 2875, 1750, 1659, 1473, 1456, 1386, 1339, 1264, 1149, 1103, 1091, 1044, 1020, 993, 974, 802, 733, 701, $422 \mathrm{~cm}^{-1}$; (400 MHz CDCl $) \delta 1.67(1 \mathrm{H}, m$, $\mathrm{H}-1), \delta 1.52$ (1H, m, H-2a), $\delta 1.80$ (1H, m, H-2b), $\delta 1.53$ (1H, m, H-3a), $\delta 2.05$ (1H, $m, \mathrm{H}-3 \mathrm{~b}), \delta 3.99\left(1 \mathrm{H}, t,{ }^{3} J\right.$ 9.0; $9.0 \mathrm{~Hz}, \mathrm{H}-4), \delta 4.48$ (1H, $\left.d,{ }^{3} J 9.5 \mathrm{~Hz}, \mathrm{H} 6\right), \delta 3.34$ (1H, $\left.m, \mathrm{H}-7\right), \delta 1.90$ (1H, $\left.m, \mathrm{H}-8 \mathrm{a}\right), \delta 2.11$ (1H, $\left.m, \mathrm{H}-8 \mathrm{~b}\right)$, $\delta 1.56$ (1H, $m, \mathrm{H}-9 \mathrm{a}), \delta 1.85$ (1H, $m, \mathrm{H}-9 \mathrm{~b}), \delta 2.08$ (1H, $m, \mathrm{H}-10), \delta 5.49$ (1H, $\left.d,{ }^{3} J 3.8 \mathrm{~Hz}, \mathrm{H}-13 \mathrm{a}\right), \delta 6.19(1 \mathrm{H}, d$, $\left.{ }^{3} J 3.5 \mathrm{~Hz}, \mathrm{H}-13 \mathrm{~b}\right), \delta 1.01$ (3H, $\left.d,{ }^{3} J 7.5 \mathrm{~Hz}, \mathrm{Me}-14\right), \delta 0.82$ (3H, s, Me-15); d $\left(100.6 \mathrm{MHz}, \mathrm{CDCl}_{3}\right) 47.8(\mathrm{C}-1)$, 23.9 (C-2), 28.1 (C-3), 82.6 (C-4), 50.8 (C-5), 90.8 (C-6), 43.2 (C-7), 22.8 (C-8), 32.6 (C-9), 33.2 (C-10), 139.8 (C-11), 169.8 (C-12), 119.8 (C-13), 14.0 (C-14), 9.0 (C-15); HRMS-ESI: [M+Na ${ }^{+}$, found 273.1467. $\mathrm{C}_{15} \mathrm{H}_{22} \mathrm{O}_{3}$ requires 273.1467.

11ß,13-dihydro-13-thiophenoxydamsin (17) and 11a,13-dihydro-13-thiophenoxydamsin (18). PhSH (300 $\mu \mathrm{L}, 2.9409 \mathrm{mmol})$ was carefully added to metallic sodium $(28.0 \mathrm{mg}, 1.2080 \mathrm{mmol})$ and when the reaction was complete, EtOH was added ( $1 \mathrm{~mL})$ and the solution was stirred at room temperature for $1 \mathrm{~h}$. Then, a solution of 1 (100 mg, $0.4027 \mathrm{mmol})$ in ethanol $(2.5 \mathrm{~mL})$ was added and the reaction was stirred at room temperature for 1 h. The reaction was quenched with 4 drops of $\mathrm{AcOH}$, followed by $2 \mathrm{~mL}$ of water. The aqueous phase was extracted with DCM $(3 \times 10 \mathrm{~mL})$, the combined organic layers were dried with $\mathrm{Na}_{2} \mathrm{SO}_{4}$ and concentrated in vacuo to give the crude product, which was purified by silicagel flash chromatography (from 15\% to 25\% EtOAc:Pet. Et.40-60) to provide the product 17 (74.6 mg, 52\%). $[\alpha]_{\mathbf{D}}{ }^{20}:+55.2\left(c 1.00, \mathrm{CH}_{2} \mathrm{Cl}_{2}\right.$ ); IR (film) = 3056, 2922, 2879, 1761, 1736, 1582, 1478, 1439, 1385, 1358, 1269, 1227, 1175, 1051, 999, 971, 949, 932, 838, 740, 691, 475 cm ${ }^{-1}$; $\left(400 \mathrm{MHz} \mathrm{CDCl}_{3}\right) \delta 2.01(1 \mathrm{H}, m, \mathrm{H}-1), \delta 1.84(1 \mathrm{H}, m, \mathrm{H}-2 \mathrm{a}), \delta 2.00(1 \mathrm{H}, m, \mathrm{H}-2 \mathrm{~b}), \delta 2.22(1 \mathrm{H}, m, \mathrm{H}-3 \mathrm{a}), \delta 2.46$ $(1 \mathrm{H}, m, \mathrm{H}-3 \mathrm{~b}), \delta 4.47\left(1 \mathrm{H}, d,{ }^{3} J 8.5 \mathrm{~Hz}, \mathrm{H}-6\right), \delta 2.75(1 \mathrm{H}, m, \mathrm{H}-7), \delta 1.70(1 \mathrm{H}, m, \mathrm{H}-8 \alpha), \delta 1.89(1 \mathrm{H}, m, \mathrm{H}-8 \beta), \delta$ 1.62 (1H, m, H-9a), $\delta 1.70$ (1H, m, H-9b), $\delta 2.17$ (1H, m, H-10), $\delta 2.58$ (1H, ddd, ${ }^{3} J$ 8.8; 7.7; $\left.3.9 \mathrm{~Hz}, \mathrm{H}-11\right), \delta$ 3.02 (1H, dd, ${ }^{3} J$ 13.6; $\left.8.9 \mathrm{~Hz}, \mathrm{H}-13 \mathrm{a}\right), \delta 3.46$ (1H, dd, ${ }^{3} J$ 13.6; $\left.3.9 \mathrm{~Hz}, \mathrm{H}-13 \mathrm{~b}\right), \delta 1.05$ (3H, $\left.d,{ }^{3} J 7.5 \mathrm{~Hz}, \mathrm{Me}-14\right)$, $\delta 1.10$ (3H, s, Me-15), $\delta 7.37$ (2H, dddd, ${ }^{3} J$ 7.7; 2.2; 1.2; $0.8 \mathrm{~Hz}, \mathrm{H}-2$ '/6'), $\delta 7.29$ (2H, dddd, ${ }^{3} J$ 7.8; 7.7; $2.2 ; 0.8$ Hz, H-3'/5'), $\delta 7.21$ (1H, dddd, ${ }^{3} J$ 7.8; 7.8; 1.2; 1.2 Hz, H-4'); d $\mathrm{C}_{\mathrm{C}}\left(100.6 \mathrm{MHz}, \mathrm{CDCl}_{3}\right) 45.8$ (C-1), 23.7 (C-2), 
35.9 (C-3), 219.0 (C-4), 54.5 (C-5), 82.1 (C-6), 45.5 (C-7), 25.3 (C-8), 33.5 (C-9), 34.1 (C-10), 46.4 (C-11), 176.7 (C-12), 34.9 (C-13), 16.0 (C-14), 14.1 (C-15), 134.8 (C-1'), 129.8 (C-2’/6’), 129.1 (C-3’/5'), 126.7 (C-4'); HRMS-ESI: $\left[\mathrm{M}+\mathrm{H}^{+}\right]$, found 359.1715. $\mathrm{C}_{21} \mathrm{H}_{26} \mathrm{O}_{3} \mathrm{~S}$ requires 359.1715. In addition, the epimer $\mathbf{1 8}$ was obtained (67.3 mg, 47\%). $[\alpha]_{\mathbf{D}}{ }^{20}:-8.0\left(c 1.00, \mathrm{CH}_{2} \mathrm{Cl}_{2}\right)$; IR (film) $=2979,2929,2876,2858,1773,1732,1579,1477$, $1437,1389,1357,1286,1164,1131,1088,965,755,692,602,580,535,473 \mathrm{~cm}^{-1} ;\left(400 \mathrm{MHz} \mathrm{CDCl}_{3}\right) \delta 2.06$ (1H, $m, \mathrm{H}-1), \delta 1.82$ (1H, m, H-2a), $\delta 2.07$ (1H, $m, \mathrm{H}-2 \mathrm{~b}), \delta 2.12$ (1H, $m, \mathrm{H}-3 \mathrm{a}), \delta 2.46$ (1H, $m, \mathrm{H}-3 \mathrm{~b}), \delta 4.47$ $\left(1 \mathrm{H}, d,{ }^{3} J 5.3 \mathrm{~Hz}, \mathrm{H}-6\right), \delta 2.59$ (1H, $\left.m, \mathrm{H}-7\right), \delta 1.51$ (1H, $\left.m, \mathrm{H}-8 \mathrm{a}\right), \delta 1.55$ (1H, $\left.m, \mathrm{H}-8 \mathrm{~b}\right), \delta 1.58$ (1H, $\left.m, \mathrm{H}-9 \mathrm{a}\right), \delta$ $1.85(1 \mathrm{H}, m, \mathrm{H}-9 \mathrm{~b}), \delta 2.20(1 \mathrm{H}, m, \mathrm{H}-10), \delta 2.90\left(1 \mathrm{H}, d d d,{ }^{3} \mathrm{~J} 10.9 ; 6.0 ; 3.5 \mathrm{~Hz}, \mathrm{H}-11\right), \delta 2.88\left(1 \mathrm{H}, d d,{ }^{3} J 13.1\right.$; $10.9 \mathrm{~Hz}, \mathrm{H}-13 \mathrm{a}), \delta 3.49$ (1H, $d d,{ }^{3} J$ 13.1; $\left.3.5 \mathrm{~Hz}, \mathrm{H}-13 \mathrm{~b}\right), \delta 1.07$ (3H, $d,{ }^{3} J$ 7.6 Hz, Me-14), $\delta 1.15$ (3H, s, Me-15), $\delta 7.36$ (2H, $d d d d,{ }^{3} J$ 7.7; 2.0; $\left.1.2 ; 0.5 \mathrm{~Hz}, \mathrm{H}-2^{\prime} / 6^{\prime}\right), \delta 7.29$ (2H, $d d d d,{ }^{3} J$ 7.8; 7.7; $1.9 ; 0.5 \mathrm{~Hz}, \mathrm{H}-3^{\prime} / 5^{\prime}$ ), $\delta 7.21\left(1 \mathrm{H}, d d d d,{ }^{3} \mathrm{~J} 7.8 ; 7.8 ; 1.2 ; 1.2 \mathrm{~Hz}, \mathrm{H}-4\right.$ ) $) \mathrm{d}_{\mathrm{C}}\left(100.6 \mathrm{MHz}, \mathrm{CDCl}_{3}\right) 45.7$ (C-1), 24.1 (C-2), 34.6 (C-3), 221.1 (C-4), 54.7 (C-5), 81.8 (C-6), 45.2 (C-7), 17.8 (C-8), 36.9 (C-9), 34.9 (C-10), 44.9 (C-11), 176.0 (C-12), 29.3 (C-13), 16.6 (C-14), 15.8 (C-15), 134.4 (C-1'), 130.0 (C-2’/6'), 129.2 (C-3’/5'), 126.9 (C-4'); HRMS-ESI: $\left[\mathrm{M}+\mathrm{H}^{+}\right]$, found 359.1708. $\mathrm{C}_{21} \mathrm{H}_{26} \mathrm{O}_{3} \mathrm{~S}$ requires 359.1715.

Indolo[3,2-c]-13-thiophenoxy-11b,13-dihydro-4-deoxydamsin (19). To a solution of 17 (189.5 mg, 0.5286 $\mathrm{mmol})$ in $\mathrm{AcOH}(8 \mathrm{~mL})$ was added phenylhydrazine $(396 \mu \mathrm{L}, 6.4086 \mathrm{mmol})$ and the reaction was stirred in a reflux system for 1 day at $120^{\circ} \mathrm{C}$. After that, 3 additional portion of phenylhydrazine $(58 \mu \mathrm{L}, 0.5894 \mathrm{mmol})$ were added, one per day. After a total reaction time of 4 days, the reaction was quenched with sat. $\mathrm{Na}_{2} \mathrm{CO}_{3}$ solution $(100 \mathrm{~mL})$ until $\mathrm{pH}=8$ and the aqueous mixture was extracted with DCM $(5 \times 30 \mathrm{~mL})$. The combined organic layers were washed with brine, dried with $\mathrm{Na}_{2} \mathrm{SO}_{4}$ and concentrated in vacuo to give the crude product, which was purified by silicagel flash chromatography (from 10\% to 20\% EtOAc:Pet.Et.40-60) to provide the product 19 (147.0 mg, 64\%). $[\alpha]_{\mathbf{D}}{ }^{20}:-87.3\left(c 1.00, \mathrm{CH}_{2} \mathrm{Cl}_{2}\right)$; IR (film) = 3396, 3054, 3002, 2921, 2855, 1763, 1582, 1479, $1448,1440,1384,1359,1305,1266,1226,1176,1129,1090,1025,995,740,691,474 \mathrm{~cm}^{-1} .\left(400 \mathrm{MHz} \mathrm{CDCl}_{3}\right)$ $\delta 2.66(1 \mathrm{H}, m, \mathrm{H}-1), \delta 2.70\left(1 \mathrm{H}, d d,{ }^{3} J 13.5 ; 6.7 \mathrm{~Hz}, \mathrm{H}-2 \mathrm{a}\right), \delta 2.91\left(1 \mathrm{H}, d d,{ }^{3} \mathrm{~J} 13.4 ; 10.3 \mathrm{~Hz}, \mathrm{H}-2 \mathrm{~b}\right), \delta 4.68(1 \mathrm{H}, \mathrm{d}$, $\left.{ }^{3} J 9.5 \mathrm{~Hz}, \mathrm{H}-6\right), \delta 2.94(1 \mathrm{H}, \mathrm{m}, \mathrm{H}-7), \delta 1.93(1 \mathrm{H}, \mathrm{m}, \mathrm{H}-8 \mathrm{a}), \delta 2.06(1 \mathrm{H}, m, \mathrm{H}-8 \mathrm{~b}), \delta 1.65(1 \mathrm{H}, \mathrm{m}, \mathrm{H}-9 \mathrm{a}), \delta 1.83$ (1H, m, H-9b), $\delta 2.31$ (1H, $m, \mathrm{H}-10), \delta 2.78(1 \mathrm{H}, m, \mathrm{H}-11), \delta 3.19\left(1 \mathrm{H}, d d,{ }^{3} \mathrm{~J} 13.5 ; 7.1 \mathrm{~Hz}, \mathrm{H}-13 \mathrm{a}\right), \delta 3.51(1 \mathrm{H}$, $d d,{ }^{3} J$ 13.5; $4.1 \mathrm{~Hz}, \mathrm{H}-13 \mathrm{~b}$ ), $\delta 1.19$ (3H, $d,{ }^{3} J 7.5 \mathrm{~Hz}, \mathrm{Me}-14$ ), $\delta 1.24$ (3H, s, Me-15), $\delta 7.43$ (1H, $m, \mathrm{H}-4$ '), $\delta 7.06$ (1H, $m, \mathrm{H}-5$ '), $\delta 7.10$ (1H, m, H-6'), $\delta 7.31$ (1H, m, H-7'), $\delta 8.26$ (1H, bs, N-H), $\delta 7.39$ (2H, m, H-2' '/6' '), $\delta 7.32$ (2H, m, H-3'”/5' '), $\delta 7.23$ (1H, m, H-4' '); d (100.6 MHz, CDCl 3 ) 46.3 (C-1), 24.8 (C-2), 115.1 (C-3/3'), 148.9 (C-4/2'), 50.7 (C-5), 87.8 (C-6), 44.0 (C-7), 24.8 (C-8), 33.3 (C-9), 34.0 (C-10), 55.9 (C-11), 177.1 (C-12), 35.1 (C-13), 14.9 (C-14), 18.0 (C-15), 124.1 (C-4a'), 118.7 (C-4'), 119.6 (C-5'), 121.0 (C-6'), 111.8 (C-7'), 139.6

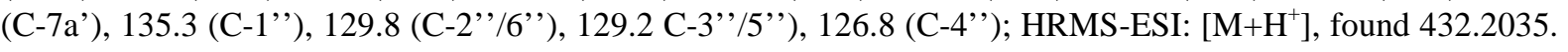
$\mathrm{C}_{21} \mathrm{H}_{23} \mathrm{NO}_{2}$ requires 432.1997 .

Indolo[3,2-c]-4-deoxydamsin(5). To a solution of 19 (130.1 mg, $0.3014 \mathrm{mmol})$ in DCM (4 mL) was added $\mathrm{m}$-CPBA $77 \%$ (67.5 mg, $0.3014 \mathrm{mmol})$ and the reaction was stirred at $-40^{\circ} \mathrm{C}$. After $3 \mathrm{~h}$, the reaction was quenched with sat. $\mathrm{NaHCO}_{3}$ solution $(2 \mathrm{~mL})$ and extracted with DCM $(3 \times 10 \mathrm{~mL})$. The combined organic layers were washed with brine ( $20 \mathrm{~mL}$ ), dried with $\mathrm{Na}_{2} \mathrm{SO}_{4}$ and concentrated in vacuo to give the crude product. Then, it was suspended in PhMe $(20 \mathrm{~mL})$ and the suspension was stirred in a reflux system at $110^{\circ} \mathrm{C}$ for $3.5 \mathrm{~h}$. The reaction was quenched allowing to reach room temperature and the solvent was evaporated in vacuo. The product was purified by silicagel flash chromatography (15\% EtOAc:Pet.Et. $\left.{ }_{40-60}\right)$ to provide the product 5 (64.1 mg, $66 \%) .[\alpha]_{\mathbf{D}}{ }^{20}:-183.8\left(c 1.00, \mathrm{CH}_{2} \mathrm{Cl}_{2}\right)$; IR (film) = 3395, 3369, 3057, 2996, 2957, 2918, 2858, 1758, 1449, 1383, 1351, 1339, 1306, 1271, 1253, 1228, 1149, 1114, 1084, 1020, 998, 971, 927, 812, 741, 711, 681, 604, 564, 532, $414 \mathrm{~cm}^{-1}$; $\left(400 \mathrm{MHz} \mathrm{CDCl}_{3}\right) \delta 2.69\left(1 \mathrm{H}, d d d,{ }^{3} J 10.0 ; 6.8 ; 3.5 \mathrm{~Hz}, \mathrm{H}-1\right), \delta 2.73\left(1 \mathrm{H}, d d,{ }^{3} J 13.2 ; 6.8 \mathrm{~Hz}, \mathrm{H}-2 \mathrm{a}\right), \delta$ $2.93\left(1 \mathrm{H}, d d,{ }^{3} J 13.1 ; 10.0 \mathrm{~Hz}, \mathrm{H}-2 \mathrm{~b}\right), \delta 4.79\left(1 \mathrm{H}, d,{ }^{3} \mathrm{~J} 9.4 \mathrm{~Hz}, \mathrm{H}-6\right), \delta 3.46\left(1 \mathrm{H}, t d t,{ }^{3} J 10.1 ; 10.1 ; 6.7 ; 3.4 ; 3.4\right.$ Hz, H-7), $\delta 2.04$ (1H, $m, \mathrm{H}-8 \mathrm{a}), \delta 2.16$ (1H, $m, \mathrm{H}-8 \mathrm{~b}), \delta 1.76$ (1H, $m, \mathrm{H}-9 \mathrm{a}), \delta 1.95$ (1H, $m, \mathrm{H}-9 \mathrm{~b}), \delta 2.35$ (1H, $m$, $\mathrm{H}-10), \delta 5.59\left(1 \mathrm{H}, d,{ }^{3} J 3.3 \mathrm{~Hz}, \mathrm{H}-13 \mathrm{a}\right), \delta 6.31\left(1 \mathrm{H}, d,{ }^{3} J 3.7 \mathrm{~Hz}, \mathrm{H}-13 \mathrm{~b}\right), \delta 1.20$ (3H, $\left.d,{ }^{3} J 7.5 \mathrm{~Hz}, \mathrm{Me}-14\right), \delta$ 1.16 (3H, s, Me-15), $\delta 7.43$ (1H, m, H-4'), $\delta 7.07\left(1 \mathrm{H}, m, \mathrm{H}-5^{\prime}\right), \delta 7.11\left(1 \mathrm{H}, m, \mathrm{H}-6\right.$ '), $\delta 7.33\left(1 \mathrm{H}, m, \mathrm{H}-7^{\prime}\right) ; \mathrm{d}_{\mathrm{C}}$ (100.6 MHz, CDCl $) 55.9$ (C-1), 28.0 (C-2), 115.0 (C-3/3'), 149.0 (C-4/2'), 50.9 (C-5), 87.3 (C-6), 42.7 (C-7), 24.4 (C-8), 33.2 (C-9), 34.1 (C-10), 139.8 (C-11), 170.4 (C-12), 120.9 (C-13), 14.8 (C-14), 17.3 (C-15),124.0 (C-3a'), 118.7 (C-4'), 119.6 (C-5'), 121.2 (C-6'), 111.8 (C-7'), 139.6 (C-7a'); HRMS-ESI: [M+H'], found 322.1816. $\mathrm{C}_{21} \mathrm{H}_{23} \mathrm{NO}_{2}$ requires 322.1807 .

4,4-(ethylenedioxy)-4-deoxydamsin (20). To a stirred solution of $\mathbf{1}$ (400 mg, $1.6108 \mathrm{mmol}$ ), p-TsOH (4.6 mg, $0.2416 \mathrm{mmol})$, ethylene glycol $(898 \mu \mathrm{L}, 16.1082 \mathrm{mmol})$ in dry DCM $(2 \mathrm{~mL})$, was added slowly ethyl orthofor- 
mate $(603 \mu \mathrm{L}, 3.6243 \mathrm{mmol})$. The reaction was stirred at room temperature for $24 \mathrm{~h}$. After that, it was quenched with a sat. $\mathrm{NaHCO}_{3}$ solution $(5 \mathrm{~mL})$, then $10 \mathrm{~mL}$ of brine were added and the aqueous layer was extracted with DCM $(3 \times 15 \mathrm{~mL})$. The combined organic layers were dried with $\mathrm{Na}_{2} \mathrm{SO}_{4}$ and concentrated in vacuo to give the crude product, which was purified by silicagel flash chromatography (20\% EtOAc:Pet. Et.40-60) to provide the product 20 (455.4 mg, 97\%). $[\alpha]_{\mathbf{D}}{ }^{20}:-83.5$ (c 1.00, $\mathrm{CH}_{2} \mathrm{Cl}_{2}$ ); IR (film) = 3323, 2968, 2945, 2903, 2878, 1751, 1659, 1469, 1385, 1302, 1271, 1176, 1135, 1053, 1021, 1003, 978, 953, 912, 804, 734, 701, $459 \mathrm{~cm}^{-1} ;(400$ $\left.\mathrm{MHz} \mathrm{CDCl}_{3}\right) \delta 2.09$ (1H, m, H-1), $\delta 1.58(1 \mathrm{H}, m, \mathrm{H}-2 \mathrm{a}), \delta 1.76(1 \mathrm{H}, m, \mathrm{H}-2 \mathrm{~b}), \delta 1.73(1 \mathrm{H}, m, \mathrm{H}-3 \mathrm{a}), \delta 1.90(1 \mathrm{H}$, $m, \mathrm{H}-3 \mathrm{~b}), \delta 4.95$ (1H, $\left.d,{ }^{3} J 9.5 \mathrm{~Hz}, \mathrm{H}-6\right), \delta 3.32$ (1H, $\left.m, \mathrm{H}-7\right), \delta 1.87$ (1H, $\left.m, \mathrm{H}-8 \mathrm{a}\right), \delta 2.02$ (1H, $\left.m, \mathrm{H}-8 \mathrm{~b}\right), \delta 1.58$ (1H, $m, \mathrm{H}-9 \mathrm{a}), \delta 1.86$ (1H, $m, \mathrm{H}-9 \mathrm{~b}), \delta 2.07$ (1H, $m, \mathrm{H}-10), \delta 5.42\left(1 \mathrm{H}, d,{ }^{3} J 3.3 \mathrm{~Hz}, \mathrm{H}-13 \mathrm{a}\right), \delta 6.13\left(1 \mathrm{H}, d,{ }^{3} J\right.$ $3.4 \mathrm{~Hz}, \mathrm{H}-13 \mathrm{~b}), \delta 1.00$ (3H, $\left.d,{ }^{3} J 7.3 \mathrm{~Hz}, \mathrm{Me}-14\right), \delta 0.93$ (3H, s, Me-15), $\delta 3.85$ (2H, m, -OC $\left.\underline{\mathrm{H}}_{2} \mathrm{CH}_{2} \mathrm{O}-\right), \delta 4.05$ (2H, m, - $\left.\mathrm{OCH}_{2} \underline{\mathrm{C}}_{2} \mathrm{O}-\right)$; $\mathrm{d}_{\mathrm{C}}\left(100.6 \mathrm{MHz} \mathrm{CDCl}_{3}\right) 46.9$ (C-1), 22.9 (C-2), 33.8 (C-3), 119.9 (C-4), 53.0 (C-5), 82.5 (C-6), 43.0 (C-7), 23.4 (C-8), 32.7 (C-9), 33.6 (C-10), 141.0 (C-11), 170.5 (C-12), 118.8 (C-13), 14.4 (C-14), 12.9 (C-15), 64.8 (-OC$\left.\underline{H}_{2} \mathrm{CH}_{2} \mathrm{O}-\right)$, $64.7\left(-\mathrm{OCH}_{2} \underline{\mathrm{C}}_{2} \mathrm{O}-\right)$; HRMS-ESI: [M + Na ${ }^{+}$, found 315.1575. $\mathrm{C}_{17} \mathrm{H}_{24} \mathrm{O}_{4}$ requires 315.1572 .

13-cyano-4,4-(ethylenedioxy)-11b,13-dihydro-4-deoxydamsin (21). To a solution of 20 (60.8 mg, 0.2081 mmol) and cynohydrin $(76.0 \mu \mathrm{L}, 0.8324 \mathrm{mmol})$ in DMSO $(2 \mathrm{~mL})$ was added NaCN $(5.0 \mathrm{mg}, 0.1020 \mathrm{mmol})$, and reaction was stirred in a reflux system at $30^{\circ} \mathrm{C}$. After $3.5 \mathrm{~h}$, the reaction was quenched with a sat. $\mathrm{NH}_{4} \mathrm{Cl}$ solution $(10 \mathrm{~mL})$, extracted with EtOAc $(3 \times 10 \mathrm{~mL})$, then the combined organic layers were dried with $\mathrm{Na}_{2} \mathrm{SO}_{4}$ and concentrated in vacuo to give the crude product, which was purified by silicagel flash chromatography (20\% EtOAc:Pet.Et.40-60) to provide the product $21(58.1 \mathrm{mg}, 87 \%) .[\alpha]_{\mathbf{D}}{ }^{20}:-136.1\left(\mathrm{c} 1.00, \mathrm{CH}_{2} \mathrm{Cl}_{2}\right)$; IR (film) = 2965, 2904, 1763, 1474, 1456, 1419, 1388, 1363, 1332, 1285, 1259, 1185, 1066, 1054, 998, 957, 940, 802, 734, 701, 673, 651, $617 \mathrm{~cm}^{-1}$;(400 MHz CDCl $) \delta 2.10$ (1H, m, H-1), $\delta 1.59$ (1H, m, H-2a), $\delta 1.77$ (1H, $\left.m, \mathrm{H}-2 \mathrm{~b}\right), \delta 1.77$ $(1 \mathrm{H}, m, \mathrm{H}-3 \beta), \delta 1.92(1 \mathrm{H}, m, \mathrm{H}-3 \alpha), \delta 4.89$ (1H, $\left.d,{ }^{3} J 9.5 \mathrm{~Hz}, \mathrm{H}-6\right), \delta 2.78(1 \mathrm{H}, m, \mathrm{H}-7), \delta 1.83$ (1H, $\left.m, \mathrm{H}-8 \mathrm{a}\right), \delta$ 2.04 (1H, m, H-8b), $\delta 1.54$ (1H, $m, \mathrm{H}-9 \mathrm{a}), \delta 1.80$ (1H, $m, \mathrm{H}-9 \mathrm{~b}), \delta 2.05$ (1H, $m, \mathrm{H}-10), \delta 2.64$ (1H, $m, \mathrm{H}-11), \delta$ 2.62 (1H, $m, \mathrm{H}-13 \mathrm{a}), \delta 2.81$ (1H, $m, \mathrm{H}-13 \mathrm{~b}), \delta 1.01$ (3H, $\left.d,{ }^{3} J 7.3 \mathrm{~Hz}, \mathrm{Me}-14\right), \delta 1.06$ (3H, s, Me-15), $\delta 3.85(2 \mathrm{H}$, m, $\left.-\mathrm{OCH}_{2} \mathrm{CH}_{2} \mathrm{O}-\right), \delta 4.01$ (2H, m, - $\left.\mathrm{OCH}_{2} \underline{\mathrm{C}}_{2} \mathrm{O}-\right)$; $\mathrm{d}_{\mathrm{C}}\left(100.6 \mathrm{MHz}, \mathrm{CDCl}_{3}\right) 47.4$ (C-1), 22.8 (C-2), $33.9(\mathrm{C}-3)$, 119.8 (C-4), 52.6 (C-5), 83.5 (C-6), 44.2 (C-7), 23.2 (C-8), 32.3 (C-9), 33.2 (C-10), 43.1 (C-11), 175.2 (C-12),

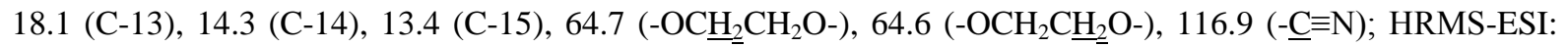
$\left[\mathrm{M}+\mathrm{Na}^{+}\right]$, found 342.1694. $\mathrm{C}_{18} \mathrm{H}_{25} \mathrm{NO}_{4}$ requires 342.1681.

4,4-(ethylenedioxy)-11b,13-dihydro-13-(N,N-dimethylaminomethyl)-4-deoxydamsin (22). A solution of 21 (645 mg, $2.0194 \mathrm{mmol})$, Pd-C 10\% (193.0 mg) and $\mathrm{Me}_{2} \mathrm{NH}$ (5.9 mL, $33.0400 \mathrm{mmol}$, sol. 5.6 M/EtOH) in EtOH $(50 \mathrm{~mL})$, was stirred in an autoclave under $\mathrm{H}_{2}(400 \mathrm{psi})$ at room temperature for 6 days. Additional Pd-C (100 mg) was added and the reaction was completed after one more day. The reaction mixture was filtered trough celite, then the pad was washed with EtOH $(2 \times 10 \mathrm{~mL})$ and the combined alcoholic extracts were concentrated in vacuo to give the crude product, which was purified by silicagel flash chromatography [ $2 \%$ (10\% $\mathrm{NH}_{4} \mathrm{OH}$ in $\left.\left.\mathrm{MeOH}\right) / \mathrm{DCM}\right]$ to give the provide 22 (674 mg, 95\%). [ $\left.\alpha\right]_{\mathbf{D}}{ }^{20}$ : $-98.9\left(\mathrm{c} 1.00, \mathrm{CH}_{2} \mathrm{Cl}_{2}\right) ; \mathrm{IR}(\mathrm{film})=$ 2968, 2941, 2901, 2864, 2817, 2766, 1758, 1463, 1385, 1360, 1299, 1225, 1175, 1123, 1073, 1043, 1007, 994, 951, 911, 733, 702, $453 \mathrm{~cm}^{-1}$; (400 $\left.\mathrm{MHz} \mathrm{CDCl}_{3}\right) \delta 2.05$ (1H, m, H-1), $\delta 1.55$ (1H, m, H-2a), $\delta 1.74(1 \mathrm{H}, m$, $\mathrm{H}-2 \mathrm{~b}), \delta 1.72$ (1H, m, H-3a), $\delta 1.91$ (1H, $m, \mathrm{H}-3 \mathrm{~b}), \delta 4.78\left(1 \mathrm{H}, d,{ }^{3} J 9.6 \mathrm{~Hz}, \mathrm{H}-6\right), \delta 2.56(1 \mathrm{H}, m, \mathrm{H}-7), \delta 1.78$ (1H, $m, \mathrm{H}-8 \mathrm{a}), \delta 1.83$ (1H, m, H-8b), $\delta 1.48$ (1H, $m, \mathrm{H}-9 \mathrm{a}), \delta 1.75$ (1H, $m, \mathrm{H}-9 \mathrm{~b}), \delta 2.03$ (1H, $m, \mathrm{H}-10), \delta 2.40$ $(1 \mathrm{H}, m, \mathrm{H}-11), \delta 1.70$ (1H, $m, \mathrm{H}-13 \mathrm{a}), \delta 1.84$ (1H, $m, \mathrm{H}-13 \mathrm{~b}), \delta 1.02\left(3 \mathrm{H}, d,{ }^{3} J 7.3 \mathrm{~Hz}, \mathrm{Me}-14\right), \delta 1.07$ (3H, s, Me-15), $\delta 2.45\left(2 \mathrm{H}, m,-\underline{\mathrm{CH}}_{2} \mathrm{~N}\left(\mathrm{CH}_{3}\right)_{2}\right), \delta 2.23\left(6 \mathrm{H}, \mathrm{s},-\mathrm{CH}_{2} \mathrm{~N}\left(\mathrm{CH}_{3}\right)_{2}\right), \delta 3.84\left(2 \mathrm{H}, m,-\mathrm{OCH}_{2} \mathrm{CH}_{2} \mathrm{O}-\right), \delta 4.02(2 \mathrm{H}$, m, $\left.-\mathrm{OCH}_{2} \mathrm{CH}_{2} \mathrm{O}-\right) ; \mathrm{d}_{\mathrm{C}}\left(100.6 \mathrm{MHz}, \mathrm{CDCl}_{3}\right) 47.3$ (C-1), 22.9 (C-2), 33.9 (C-3), 120.1 (C-4), 52.8 (C-5), 82.7 (C-6), 45.0 (C-7), 23.8 (C-8), 33.0 (C-9), 33.5 (C-10), 44.3 (C-11), 179.0 (C-12), 28.3 (C-13), 14.5 (C-14), 13.7 (C-15), $56.5\left(-\mathrm{CH}_{2} \mathrm{~N}\left(\mathrm{CH}_{3}\right)_{2}\right), 45.3\left(-\mathrm{CH}_{2} \mathrm{~N}\left(\mathrm{CH}_{3}\right)_{2}\right), 64.8\left(-\mathrm{OC}_{2}{ }_{2} \mathrm{CH}_{2} \mathrm{O}-\right), 64.7\left(-\mathrm{OCH}_{2} \underline{\mathrm{H}}_{2} \mathrm{O}-\right)$; HRMS-ESI: $\left[\mathrm{M}+\mathrm{H}^{+}\right]$, found 352.2494. $\mathrm{C}_{20} \mathrm{H}_{33} \mathrm{NO}_{4}$ requires 352.2488.

11b-bromo-4,4-(ethylenedioxy)-13-hydro-13-(N,N-dimethylaminomethyl)-4-deoxydamsin (23). To a so-

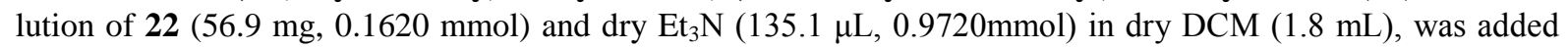
TMSOTf $(93.9 \mu \mathrm{L}, 0.4860 \mathrm{mmol})$ and the mixture was stirred at $0^{\circ} \mathrm{C}$ for $2 \mathrm{~h}$. Then, TMPAP $(182.7 \mathrm{mg}, 0.4860$ mmol) was added as solution in dry DCM $(2.5 \mathrm{~mL})$ and the reaction was stirred at $0^{\circ} \mathrm{C}$ for exactly $1.75 \mathrm{~h}$. The reaction was quenched with a $10 \% \mathrm{Na}_{2} \mathrm{~S}_{2} \mathrm{O}_{3}$ sol. $(10 \mathrm{~mL})$ and sat. $\mathrm{NaHCO}_{3}$ solution $(10 \mathrm{~mL})$, extracted with $\operatorname{DCM}(4 \times 10 \mathrm{~mL})$, whereafter the combined organic layers were dried with $\mathrm{Na}_{2} \mathrm{SO}_{4}$ and concentrated in vacuo to give the crude product, which was purified by silicagel flash chromatography [from $1 \%$ to $3 \%\left(10 \% \mathrm{NH}_{4} \mathrm{OH}\right.$ 
in $\mathrm{MeOH}) / \mathrm{DCM}]$ to give the product 23 (38.9 mg, 67\%). $[\alpha]_{\mathbf{D}}{ }^{20}:-58.6\left(c 1.00, \mathrm{CH}_{2} \mathrm{Cl}_{2}\right)$; IR (film) = 3440, 2961, 2901, 2824, 2770, 2623, 2465, 1750, 1673, 1474, 1387, 1345, 1264, 1197, 1106, 1049, 1013, 985, 954, 923, 800, 731, 699, 566, $411 \mathrm{~cm}^{-1}$; (400 MHz CDCl $) \delta 2.12\left(1 \mathrm{H}, t d,{ }^{3} J 9.5 ; 9.5 ; 3.5 \mathrm{~Hz}, \mathrm{H}-1\right), \delta 1.65(1 \mathrm{H}, m, \mathrm{H}-2 \mathrm{a}), \delta 1.68$ (1H, m, H-2b), $\delta 1.72$ (1H, m, H-3a), $\delta 1.87$ (1H, $m, \mathrm{H}-3 \mathrm{~b}), \delta 5.29$ (1H, $\left.d,{ }^{3} J 5.3 \mathrm{~Hz}, \mathrm{H}-6\right), \delta 2.67$ (1H, $\left.m, \mathrm{H}-7\right), \delta$ 1.58 (1H, $m, \mathrm{H}-8 \mathrm{a}), \delta 1.58$ (1H, $m, \mathrm{H}-8 \mathrm{~b}), \delta 1.54$ (1H, $m, \mathrm{H}-9 \mathrm{a}), \delta 1.81$ (1H, $m, \mathrm{H}-9 \mathrm{~b}), \delta 2.01$ (1H, $m, \mathrm{H}-10), \delta$ $1.99\left(1 \mathrm{H}, d d d,{ }^{3} J 14.8 ; 10.6 ; 4.0 \mathrm{~Hz}, \mathrm{H}-13 \mathrm{a}\right), \delta 2.38$ (1H, ddd, $\left.{ }^{3} J 15.0 ; 11.5 ; 4.7 \mathrm{~Hz}, \mathrm{H}-13 \mathrm{~b}\right), \delta 1.00$ (3H, $d,{ }^{3} J 7.5$ Hz, Me-14), $\delta 1.15$ (3H, s, Me-15), $\delta 2.52\left(1 \mathrm{H}, t d,{ }^{3} J 11.8 ; 11.8 ; 3.9 \mathrm{~Hz},-\mathrm{CH}_{\mathrm{a}} \mathrm{H}_{\mathrm{b}} \mathrm{N}\left(\mathrm{CH}_{3}\right)_{2}\right), \delta 2.82\left(1 \mathrm{H}, d d d,{ }^{3} J\right.$ 11.9; 10.8; $\left.4.7 \mathrm{~Hz},-\mathrm{CH}_{\mathrm{a}} \underline{\mathrm{H}}_{\underline{b}} \mathrm{~N}\left(\mathrm{CH}_{3}\right)_{2}\right), \delta 2.31\left(6 \mathrm{H}, \mathrm{s},-\mathrm{CH}_{\mathrm{a}} \mathrm{H}_{\mathrm{b}} \mathrm{N}\left(\mathrm{C}_{3}\right)_{2}\right), \delta 3.93\left(2 \mathrm{H}, m_{,}-\mathrm{OC}_{2} \mathrm{CH}_{2} \mathrm{O}-\right), \delta 3.98(2 \mathrm{H}$, m, $\left.-\mathrm{OCH}_{2} \mathrm{CH}_{2} \mathrm{O}-\right) ; \mathrm{d}_{\mathrm{C}}\left(100.6 \mathrm{MHz} \mathrm{CDCl}_{3}\right) 44.1$ (C-1), 23.3 (C-2), 31.1 (C-3), 119.8 (C-4), 51.1 (C-5), 79.8 (C-6), 56.1 (C-7), 19.9 (C-8), 36.8 (C-9), 34.4 (C-10), 64.7 (C-11), 173.6 (C-12), 32.1 (C-13), 16.1 (C-14), 16.4 (C-5), $55.6\left(-\underline{\mathrm{CH}}_{2} \mathrm{~N}\left(\mathrm{CH}_{3}\right)_{2}\right), 45.3\left(-\mathrm{CH}_{2} \mathrm{~N}\left(\underline{\mathrm{CH}}_{3}\right)_{2}\right), 65.3\left(-\mathrm{OCH}_{2} \underline{C H}_{2} \mathrm{O}-\right), 64.7\left(-\mathrm{OCH}_{2} \underline{\mathrm{CH}}_{2} \mathrm{O}-\right)$; HRMS-ESI: $\left[\mathrm{M}+\mathrm{H}^{+}\right]$, found $430.1561 . \mathrm{C}_{20} \mathrm{H}_{32} \mathrm{BrNO}_{4}$ requires 430.1593 .

(E)-4,4-(ethylenedioxy)-13-(N,N-dimethylaminomethyl)-4-deoxydamsin (24). To a solution of 23 (157.2 $\mathrm{mg}, 0.3653 \mathrm{mmol})$ in dry THF $(7 \mathrm{~mL})$ was added TBAF $(730.6 \mu \mathrm{L}, 0.7306 \mathrm{mmol})$, and the reaction was stirred at room temperature. After $11.5 \mathrm{~h}$, the reaction was quenched adding a sat. $\mathrm{NaHCO}_{3}$ solution $(20 \mathrm{~mL})$ and the mixture was extracted with DCM $(3 \times 20 \mathrm{~mL})$. The combined organic layers were dried with $\mathrm{Na}_{2} \mathrm{SO}_{4}$ and concentrated in vacuo to give the crude product, which was purified by silicagel flash chromatography [2\% (10\% $\mathrm{NH}_{4} \mathrm{OH}$ in $\left.\left.\mathrm{MeOH}\right) / \mathrm{DCM}\right]$ to provide the product 24 (95.1 mg, 75\%). $[\alpha]_{\mathbf{D}}{ }^{20}:-80.9\left(c 1.00, \mathrm{CH}_{2} \mathrm{Cl}_{2}\right) ; \mathrm{IR}($ film $)=$ 2966, 2943, 2875, 2819, 2769, 1749, 1674, 1455, 1385, 1312, 1263, 1234, 1206, 1175, 1153, 1125, 1040, 1006, 985, 953, 911, 838, 728, 643, $466 \mathrm{~cm}^{-1}$; (400 MHz CDCl $) \delta 2.10\left(1 \mathrm{H}, \mathrm{td},{ }^{3} J\right.$ 9.6; 9.6; 4.0Hz, H-1), $\delta 1.62(1 \mathrm{H}$, $m, \mathrm{H}-2 \mathrm{a}), \delta 1.69$ (1H, m, H-2b), $\delta 1.71$ (1H, $m, \mathrm{H}-3 \mathrm{a}), \delta 1.90$ (1H, $m, \mathrm{H}-3 \mathrm{~b}), \delta 4.92$ (1H, $\left.d,{ }^{3} J 8.2 \mathrm{~Hz}, \mathrm{H}-6\right), \delta$ 3.24 (1H, m, H-7), $\delta 1.66$ (1H, $m, \mathrm{H}-8 \mathrm{a}), \delta 1.97$ (1H, $m, \mathrm{H}-8 \mathrm{~b}), \delta 1.59$ (1H, $m, \mathrm{H}-9 \mathrm{a}), \delta 1.78$ (1H, $m, \mathrm{H}-9 \mathrm{~b}), \delta$ $2.02(1 \mathrm{H}, m, \mathrm{H}-10), \delta 6.72\left(1 \mathrm{H}, d d d,{ }^{3} J\right.$ 7.8; 5.5; $\left.2.6 \mathrm{~Hz}, \mathrm{H}-13\right), \delta 1.02\left(3 \mathrm{H}, d,{ }^{3} J 7.4 \mathrm{~Hz}, \mathrm{Me}-14\right), \delta 1.11(3 \mathrm{H}, s$,

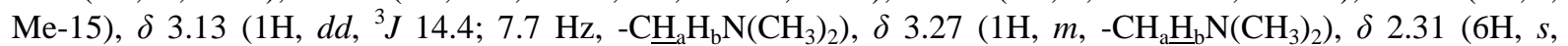
$\left.-\mathrm{CH}_{\mathrm{a}} \mathrm{H}_{\mathrm{b}} \mathrm{N}\left(\mathrm{C}_{3}\right)_{2}\right), \delta 3.88\left(2 \mathrm{H}, m,-\mathrm{OCH}_{2} \mathrm{CH}_{2} \mathrm{O}-\right), \delta 3.97\left(2 \mathrm{H}, m,-\mathrm{OCH}_{2} \mathrm{CH}_{2} \mathrm{O}-\right)$; $\mathrm{d}_{\mathrm{C}}\left(100.6 \mathrm{MHz}^{-} \mathrm{CDCl}_{3}\right) 45.2$ (C-1), 23.2 (C-2), 32.5 (C-3), 119.9 (C-4), 52.5 (C-5), 80.1 (C-6), 44.6 (C-7), 24.9 (C-8), 35.7 (C-9), 34.2 (C-10), 134.7 (C-11), 170.7 (C-12), 135.1 (C-13), 15.4 (C-14), $14.9(\mathrm{C}-15), 56.9\left(-\underline{\mathrm{CH}}_{2} \mathrm{~N}\left(\mathrm{CH}_{3}\right)_{2}\right), 45.1\left(-\mathrm{CH}_{2} \mathrm{~N}\left(\underline{\mathrm{CH}}_{3}\right)_{2}\right)$, $64.7\left(-\mathrm{OCH}_{2} \mathrm{CH}_{2} \mathrm{O}-\right), 65.0\left(-\mathrm{OCH}_{2} \underline{\mathrm{CH}}_{2} \mathrm{O}-\right)$; HRMS-ESI: [M+H $\left.{ }^{+}\right]$, found 350.2313. $\mathrm{C}_{20} \mathrm{H}_{31} \mathrm{NO}_{4}$ requires 350.2331.

(E)-13-(N,N-dimethylaminomethyl)damsin (8). To a solution of 24 (19.7 mg, $0.0564 \mathrm{mmol})$ in $\mathrm{MeOH}(0.4$ $\mathrm{mL})$ was added $\mathrm{HCl}_{\text {(Conc) }}(200 \mu \mathrm{L}, 2.3303 \mathrm{mmol})$ and the reaction stirred at room temperature. After $6 \mathrm{~h}$, the reaction was quenched with sat. $\mathrm{NaHCO}_{3}$ solution $(15 \mathrm{~mL})$ and the aqueous solution was extracted with DCM (5 $\times 10 \mathrm{~mL}$ ). The combined organic layers were dried with $\mathrm{Na}_{2} \mathrm{SO}_{4}$ and concentrated in vacuo to give the crude product, which was purified by silicagel flash chromatography [2\% (10\% $\mathrm{NH}_{4} \mathrm{OH}$ in $\left.\mathrm{MeOH}\right) / \mathrm{DCM}$ ] to provide the product $8(14.5 \mathrm{mg}, 84 \%)$. $[\alpha]_{\mathbf{D}}{ }^{20}:+3.0\left(c 1.00, \mathrm{CH}_{2} \mathrm{Cl}_{2}\right)$; IR (film) = 2940, 2862, 2821, 2772, 2723, 1738, 1677, 1454, 1407, 1386, 1372, 1333, 1315, 1263, 1209, 1153, 1132, 1096, 1050, 1012, 987, 838, 798, 536 cm ${ }^{-1}$; $\left(400 \mathrm{MHz} \mathrm{CDCl}_{3}\right) \delta 2.05$ (1H, $\left.m, \mathrm{H}-1\right), \delta 1.84$ (1H, $\left.m, \mathrm{H}-2 \mathrm{a}\right), \delta 2.06$ (1H, $\left.m, \mathrm{H}-2 \mathrm{~b}\right), \delta 2.20(1 \mathrm{H}, m, \mathrm{H}-3 \mathrm{a}), \delta 2.46$ (1H, m, H-3b), $\delta 4.45$ (1H, $\left.d,{ }^{3} J 7.3 \mathrm{~Hz}, \mathrm{H}-6\right), \delta 3.15$ (1H, m, H-7), $\delta 1.47$ (1H, dd, $\left.{ }^{3} J 15.0 ; 6.8 \mathrm{~Hz}, \mathrm{H}-8 \mathrm{a}\right), \delta 1.94$ (1H, $m, \mathrm{H}-8 \mathrm{~b}), \delta 1.72$ (1H, $m, \mathrm{H}-9 \mathrm{a}), \delta 1.85$ (1H, $m, \mathrm{H}-9 \mathrm{~b}), \delta 2.21$ (1H, $m, \mathrm{H}-10), \delta 6.74$ (1H, ddd, ${ }^{3} J$ 7.7; 5.5; $2.0 \mathrm{~Hz}, \mathrm{H}-13 \mathrm{a}), \delta 1.09\left(3 \mathrm{H}, d,{ }^{3} J 7.6 \mathrm{~Hz}, \mathrm{Me}-14\right), \delta 1.19(3 \mathrm{H}, \mathrm{s}, \mathrm{Me}-15), \delta 3.05\left(1 \mathrm{H}, d d,{ }^{3} J 15.1 ; 7.8 \mathrm{~Hz}\right.$ $\left.\left.-\mathrm{CH}_{\underline{a}} \mathrm{H}_{\mathrm{b}} \mathrm{N}\left(\mathrm{CH}_{3}\right)_{2}\right), \delta 3.19\left(1 \mathrm{H}, d d,{ }^{3} J 15.0 ; 5.6 \mathrm{~Hz},-\mathrm{CH}_{\mathrm{a}} \underline{\mathrm{H}}_{\mathrm{b}} \mathrm{N}\left(\mathrm{CH}_{3}\right)_{2}\right), \delta 2.28\left(6 \mathrm{H}, \mathrm{s},-\mathrm{CH}_{\mathrm{a}} \mathrm{H}_{\mathrm{b}} \mathrm{N}_{(\mathrm{C}} \underline{\mathrm{C}}_{3}\right)_{2}\right) ; \mathrm{d}_{\mathrm{C}}(100.6$ $\mathrm{MHz}, \mathrm{CDCl}_{3}$ ) 46.0 (C-1), 24.3 (C-2), 34.7 (C-3), 220.4 (C-4), 54.8 (C-5), 80.7 (C-6), 45.1 (C-7), 25.9 (C-8), 36.6 (C-9), 35.1 (C-10), 134.2 (C-11), 170.1 (C-12), 136.4 (C-13), 16.2 (C-14), 15.1 (C-15), 57.3 $\left(-\underline{C H}_{2} \mathrm{~N}\left(\mathrm{CH}_{3}\right)_{2}\right), 45.3\left(-\mathrm{CH}_{2} \mathrm{~N}\left(\underline{C H}_{3}\right)_{2}\right)$; HRMS-ESI: [M+H $\left.{ }^{+}\right]$, found 306.2070. $\mathrm{C}_{18} \mathrm{H}_{27} \mathrm{NO}_{3}$ requires 306.2069.

4,4-(ethylenedioxy)-4-deoxyisodamsin (25). To a stirred solution of 7 (100 mg, $0.4027 \mathrm{mmol})$, p-TsOH (2.3 $\mathrm{mg}, 0.1208 \mathrm{mmol})$, ethylene glycol $(450 \mu \mathrm{L}, 8.0540 \mathrm{mmol})$ in dry DCM $(2 \mathrm{~mL})$ was added slowly ethyl orthoformate $(301 \mu \mathrm{L}, 1.8121 \mathrm{mmol})$, and the reaction was stirred at room temperature for $24 \mathrm{~h}$. The reaction was quenched with a sat. $\mathrm{NaHCO}_{3}$ solution $(20 \mathrm{~mL})$ and the aqueous mixture was extracted with DCM (5x20 mL). The combined organic layers were washed with brine $(15 \mathrm{~mL})$, dried with $\mathrm{Na}_{2} \mathrm{SO}_{4}$ and concentrated in vacuo to give the crude product, which was purified by silicagel flash chromatography (from 10\% to 20\% EtOAc: Pet.Et.40-60) to provide the product $25(113.0 \mathrm{mg}, 96 \%)$. $[\alpha]_{\mathbf{D}}{ }^{20}:-33.6\left(c 1.00, \mathrm{CH}_{2} \mathrm{Cl}_{2}\right)$; IR (film) = 3055, 2967, 2945, 2917, 2879, 1743, 1663, 1471, 1458, 1422, 1384 1322, 1303, 1263, 1180, 1147, 1100, 1077, 1050, 1017, 998, 952, 916, 880, 800, 731, 701, 648, $533 \mathrm{~cm}^{-1}$; (400 MHz $\left.\mathrm{CDCl}_{3}\right) \delta 2.25(1 \mathrm{H}, m, \mathrm{H}-1), \delta 1.58(1 \mathrm{H}, m, \mathrm{H}-2 \mathrm{a})$, 
$\delta 1.72(1 \mathrm{H}, m, \mathrm{H}-2 \mathrm{~b}), \delta 1.80$ (1H, $m, \mathrm{H}-3 \mathrm{a}), \delta 1.92$ (1H, $m, \mathrm{H}-3 \mathrm{~b}), \delta 5.07$ (1H, s, H-6), $\delta 2.60$ (1H, $m, \mathrm{H}-8 \mathrm{a}), \delta$ $2.64(1 \mathrm{H}, m, \mathrm{H}-8 \mathrm{~b}), \delta 1.73(1 \mathrm{H}, m, \mathrm{H}-9 \mathrm{a}), \delta 1.80(1 \mathrm{H}, m, \mathrm{H}-9 \mathrm{~b}), \delta 2.09(1 \mathrm{H}, m, \mathrm{H}-10), \delta 1.77\left(3 \mathrm{H}, d,{ }^{3} J 1.5 \mathrm{~Hz}\right.$, Me-13), $\delta 0.94$ (3H, $d,{ }^{3} J 7.5 \mathrm{~Hz}$, Me-14), $\delta 0.70$ (3H, s, Me-15), $\delta 3.86\left(2 \mathrm{H}, m,-\mathrm{OCH}_{2} \mathrm{CH}_{2} \mathrm{O}-\right), \delta 4.09(2 \mathrm{H}, m$, $\left.-\mathrm{OCH}_{2} \mathrm{CH}_{2} \mathrm{O}-\right)$; d $\mathrm{d}_{\mathrm{C}}\left(100.6 \mathrm{MHz}, \mathrm{CDCl}_{3}\right) 48.1$ (C-1), 23.1 (C-2), 34.5 (C-3), 119.1 (C-4), 51.7 (C-5), 85.3 (C-6), 163.8 (C-7), 22.2 (C-8), 31.2 (C-9), 33.2 (C-10), 123.5 (C-11), 174.9 (C-12), 8.4 (C-13), 13.7 (C-14), 11.1 (C-15), 66.0 (- $\left.\mathrm{OCH}_{2} \mathrm{CH}_{2} \mathrm{O}-\right)$, $64.8\left(-\mathrm{OCH}_{2} \mathrm{CH}_{2} \mathrm{O}-\right)$; HRMS-ESI: [M+H'] found 293.1750. $\mathrm{C}_{17} \mathrm{H}_{24} \mathrm{O}_{4}$ requires 293.1753.

4,4-(ethylenedioxy)-6 $\boldsymbol{\alpha}$-hydroxy-4-deoxyisodamsin (27). i) To a stirred solution of 25 (303.8 mg, 1.0398 $\mathrm{mmol})$ and TDMSOTf $(465.0 \mu \mathrm{L}, 2.0247 \mathrm{mmol})$ in dry DCM $(10 \mathrm{~mL})$ at $0^{\circ} \mathrm{C}$, was added dry TEA $(303.0 \mu \mathrm{L}$, $2.1800 \mathrm{mmol}$ ) dropwise. The reaction was allowed to reach room temperature and after 3 days, quenched with water $(10 \mathrm{~mL})$. Then the mixture was extracted with DCM $(3 \times 10 \mathrm{~mL})$, dried with $\mathrm{Na}_{2} \mathrm{SO}_{4}$ and concentarted in vacuo to give the crude intermediate. ii) The crude of the previous step was dissolved in dry DCM $(9 \mathrm{~mL})$ and $m$-CPBA $77 \%$ (233.0 mg, $1.0398 \mathrm{mmol}$ ) was added, the reaction was stirred at room temperature for $5 \mathrm{~h}$. The reaction was quenched with a $10 \% \mathrm{Na}_{2} \mathrm{~S}_{2} \mathrm{O}_{3}$ solution $(1 \mathrm{~mL})$, then brine was added $(10 \mathrm{~mL})$ and the aqueous mixture was extracted with DCM $(4 \times 15 \mathrm{~mL})$. The combined organic layers were dried with $\mathrm{Na}_{2} \mathrm{SO}_{4}$ and concentrated in vacuo. The product was purified by silicagel flash chromatography (from $15 \%$ to $20 \%$ EtOAc: Pet.Et. $\left.{ }_{40-60}\right)$ to provide the product $27(233.3 \mathrm{mg}, 73 \%)$. $[\alpha]_{\mathbf{D}}{ }^{20}:-21.1\left(\mathrm{c} 1.00, \mathrm{CH}_{2} \mathrm{Cl}_{2}\right)$; IR (film) = 3378, 2943, 2915, 2882, 1753, 1674, 1473, 1430, 1385, 1304, 1223, 1182, 1155, 1131, 1116, 1077, 1050, 1001, 973, 941, 903, 762, 646, 535, $453 \mathrm{~cm}^{-1}$; $\left(400 \mathrm{MHz} \mathrm{CDCl}_{3}\right) \delta 2.73\left(1 \mathrm{H}, d d d,{ }^{3} \mathrm{~J} 12.4 ; 7.4 ; 4.8 \mathrm{~Hz}, \mathrm{H}-1\right), \delta 1.59(1 \mathrm{H}, \mathrm{m}$, $\mathrm{H}-2 \mathrm{a}), \delta 1.71$ (1H, $m, \mathrm{H}-2 \mathrm{~b}), \delta 1.85$ (1H, $m, \mathrm{H}-3 \mathrm{a}), \delta 1.92$ (1H, $m, \mathrm{H}-3 \mathrm{~b}), \delta 2.60$ (1H, $m, \mathrm{H}-8 \mathrm{a}), \delta 2.60$ (1H, $m$, $\mathrm{H}-8 \mathrm{~b}), \delta 1.62$ (1H, $m, \mathrm{H}-9 \mathrm{a}), \delta 2.28$ (1H, $m, \mathrm{H}-9 \mathrm{~b}), \delta 2.14$ (1H, $m, \mathrm{H}-10), \quad \delta 1.77$ (3H, $\left.t,{ }^{3} J 1.4 ; 1.4 \mathrm{~Hz}, \mathrm{Me}-13\right)$, $\delta 0.95\left(3 \mathrm{H}, d,{ }^{3} J 7.6 \mathrm{~Hz}, \mathrm{Me}-14\right), \delta 0.82$ (3H, s, Me-15), $\delta 3.90\left(2 \mathrm{H}, m,-\mathrm{OCH}_{2} \mathrm{CH}_{2} \mathrm{O}-\right), \delta 4.15(2 \mathrm{H}, m$, $\left.-\mathrm{OCH}_{2} \mathrm{CH}_{2} \mathrm{O}-\right), \delta 6.53(1 \mathrm{H}, s,-\mathrm{OH}) ; \mathrm{d}_{\mathrm{C}}\left(100.6 \mathrm{MHz}, \mathrm{CDCl}_{3}\right) 46.1$ (C-1), 23.1 (C-2), 36.2 (C-3), 121.4 (C-4), 53.4 (C-5), 110.1 (C-6), 160.5 (C-7), 21.9 (C-8), 29.8 (C-9), 33.4 (C-10), 125.3 (C-11), 172.9 (C-12), 8.2 (C-13), 14.1 (C-14), 14.1 (C-15), 64.9 (- $\left.\mathrm{OCH}_{2} \mathrm{CH}_{2} \mathrm{O}-\right)$, 64.4 (-OCH$\left.{ }_{2} \mathrm{CH}_{2} \mathrm{O}-\right)$; HRMS-ESI: [M + $\mathrm{H}^{+}$], found 309.1711. $\mathrm{C}_{17} \mathrm{H}_{24} \mathrm{O}_{5}$ requires 309.1702 .

6 $\boldsymbol{\alpha}$-hydroxyisodamsin $(\mathbf{9})$. To a solution of $27(152.1 \mathrm{mg}, 0.4932 \mathrm{mmol})$ in $\mathrm{MeOH}(5 \mathrm{~mL})$ was added $\mathrm{HCl}_{\text {(Conc) }}(1 \mathrm{~mL}, 11.6511 \mathrm{mmol})$ and the reaction was stirred at room temperature. After $4.5 \mathrm{~h}$, the reaction was quenched with sat. $\mathrm{NaHCO}_{3}$ solution $(10 \mathrm{~mL})$ and the aqueous mixture was extracted with DCM $(4 \times 30 \mathrm{~mL})$. The combined organic layers were dried with $\mathrm{Na}_{2} \mathrm{SO}_{4}$ and concentrated in vacuo to give the crude product, which was purified by silicagel flash chromatography (45\% EtOAc:Pet.Et.40-60) to provide the product 9 (94.3 $\mathrm{mg}, 72 \%) .[\alpha]_{\mathbf{D}}{ }^{20}:+43.6\left(c 1.00, \mathrm{CH}_{2} \mathrm{Cl}_{2}\right)$; IR (film) $=3292,2966,2951,2931,2867,1727,1677,1453,1411$, 1376, 1270, 1242, 1214, 1169, 1153, 1087, 1058, 1013, 976, 958, 885, 867, 802, 759, 733, 702, 688, 662, 554, $418 \mathrm{~cm}^{-1}$; $\left(400 \mathrm{MHz} \mathrm{CDCl}_{3}\right) \delta 3.01\left(1 \mathrm{H}, d t,{ }^{3} J 12.4 ; 6.0 ; 6.0 \mathrm{~Hz}, \mathrm{H}-1\right), \delta 1.74(1 \mathrm{H}, \mathrm{m}, \mathrm{H}-2 \mathrm{a}), \delta 1.85(1 \mathrm{H}, m$, $\mathrm{H}-2 \mathrm{~b}), \delta 2.32$ (1H, $m, \mathrm{H}-3 \mathrm{a}), \delta 2.32$ (1H, $m, \mathrm{H}-3 \mathrm{~b}), \delta 2.41$ (1H, $m, \mathrm{H}-8 \mathrm{a}), \delta 2.62$ (1H, ddd, ${ }^{3} J$ 14.0; 6.6; $1.2 \mathrm{~Hz}$, H-8b), $\delta 1.12$ (1H, $m, \mathrm{H}-9 \mathrm{a}$ ), $\delta 2.20$ (1H, $m, \mathrm{H}-9 \mathrm{~b}), \delta 2.19$ (1H, $m, \mathrm{H}-10$ ), $\delta 1.73$ (3H, s, Me-13), $\delta 0.92$ (3H, $d,{ }^{3} J$ $6.8 \mathrm{~Hz}, \mathrm{Me}-14), \delta 0.82(3 \mathrm{H}, \mathrm{s}, \mathrm{Me}-15), \delta 4.71\left(1 \mathrm{H}, b s,{ }^{3} \mathrm{~J} \mathrm{~Hz},-\mathrm{OH}\right) ; \mathrm{d}_{\mathrm{C}}\left(100.6 \mathrm{MHz}, \mathrm{CDCl}_{3}\right) 41.4(\mathrm{C}-1)$, 23.6(C-2), 39.6 (C-3), 218.3 (C-4), 56.1 (C-5), 107.7 (C-6), 161.4 (C-7), 22.3 (C-8), 32.8 (C-9), 33.0 (C-10), 125.0 (C-11), 172.6 (C-12), 7.9 (C-13), 17.6 (C-14), 14.0 (C-15); HRMS-ESI: [M + $\mathrm{H}^{+}$], found 265.1466. $\mathrm{C}_{15} \mathrm{H}_{20} \mathrm{O}_{4}$ requires 265.1440 .

13-phenylisodamsin (10). A solution of 1 (150 mg, $0.6040 \mathrm{mmol}), \mathrm{Pd}(\mathrm{OAc})_{2}$ (5.0 mg, $\left.0.0242 \mathrm{mmol}\right)$, Tri(p-Tolyl)P (29.0 mg, $0.0966 \mathrm{mmol}), \mathrm{PhI}(81.0 \mu \mathrm{L}, 0.7248 \mathrm{mmol})$ and $\mathrm{Et}_{3} \mathrm{~N}(151 \mu \mathrm{L}, 1.0872 \mathrm{mmol})$ in DMF $(1.6 \mathrm{~mL})$, in a sealed tube was stirred at $120^{\circ} \mathrm{C}$ for 4.5 days. After that time the reaction was not complete, therefore a second addition of $\mathrm{Pd}(\mathrm{OAc})_{2}(5.0 \mathrm{mg}, 0.0242 \mathrm{mmol})$, Tri(p-Tolyl)P $(29.0 \mathrm{mg}, 0.0966 \mathrm{mmol}), \mathrm{PhI}$ $(81.0 \mu \mathrm{L}, 0.7248 \mathrm{mmol})$ and $\mathrm{Et}_{3} \mathrm{~N}(151 \mu \mathrm{L}, 1.0872 \mathrm{mmol})$ as solution in DMF $(1.6 \mathrm{~mL})$ was done. The reaction was stirred for was stirred at $120^{\circ} \mathrm{C}$ for $30 \mathrm{~h}$. When the reaction was complete, it was quenched with water (25 $\mathrm{mL})$, and the aqueous mixture was extracted with DCM $(5 \times 20 \mathrm{~mL})$. The combined organic layers were dried with $\mathrm{Na}_{2} \mathrm{SO}_{4}$ and contrated in vacuo to give the crude product, which was purified by silicagel flash chromatography (30\% EtOAc:Pet. Et. $\left.{ }_{40-60}\right)$ to provide the product $10(112.0 \mathrm{mg}, 57 \%)$. $[\alpha]_{\mathbf{D}}{ }^{20}:-14.1\left(c 1.00, \mathrm{CH}_{2} \mathrm{Cl}_{2}\right)$; IR $($ film $)=2961,2923,2878,1737,1664,1494,1454,1301,1154,1121,1068,1022,990,967,884,805,732,700$ $\mathrm{cm}^{-1}$; $\left(400 \mathrm{MHz} \mathrm{CDCl}_{3}\right) \delta 2.30(1 \mathrm{H}, m, \mathrm{H}-1), \delta 1.92$ (1H, $\left.m, \mathrm{H}-2 \mathrm{a}\right), \delta 1.94(1 \mathrm{H}, m, \mathrm{H}-2 \mathrm{~b}), \delta 2.32(1 \mathrm{H}, m, \mathrm{H}-3 \mathrm{a})$, $\delta 2.47\left(1 \mathrm{H}, d d d,{ }^{3} J 18.3 ; 7.1 ; 1.6 \mathrm{~Hz}, \mathrm{H}-3 \mathrm{~b}\right), \delta 4.64(1 \mathrm{H}, \mathrm{s}, \mathrm{H}-6), \delta 2.31(1 \mathrm{H}, \mathrm{m}, \mathrm{H}-8 \mathrm{a}), \delta 2.82\left(1 \mathrm{H}, d d,{ }^{3} J 14.9\right.$; $8.0 \mathrm{~Hz}, \mathrm{H}-8 \mathrm{~b}), \delta 1.15$ (1H, m, H-9a), $\delta 2.03$ (1H, m, H-9b), $\delta 2.21$ (1H, m, H-10), $\delta 3.58$ (1H, dso, ${ }^{3} J 14.8 \mathrm{~Hz}$, 
H-13a), $\delta 3.65$ (1H, dso, ${ }^{3} J 14.8 \mathrm{~Hz}, \mathrm{H}-13 \mathrm{~b}$ ), $\delta 0.94$ (3H, $\left.d,{ }^{3} J 7.2 \mathrm{~Hz}, \mathrm{Me}-14\right), \delta 0.79$ (3H, s, Me-15), $\delta 7.28$ (2H, $m, \mathrm{H}-2^{\prime} / 6^{\prime}$ ), $\delta 7.25$ (2H, $\left.m, \mathrm{H}-3^{\prime} / 5^{\prime}\right), \delta 7.21$ (1H, m, H-4'); $\mathrm{d}_{\mathrm{C}}\left(100.6 \mathrm{MHz}, \mathrm{CDCl}_{3}\right) 44.1$ (C-1), 23.7 (C-2), 37.3 (C-3), 217.4 (C-4), 52.7 (C-5), 84.7 (C-6), 162.5 (C-7), 23.4 (C-8), 32.0 (C-9), 32.9 (C-10), 127.6 (C-11), 174.0 (C-12), 29.3 (C-13), 17.2 (C-14), 11.2 (C-15), 138.2 (C-1'), 128.3 (C-2'/6'), 128.5 (C-3’/5'), 126.4 (C-4'); $\left[\mathrm{M}+\mathrm{H}^{+}\right]$, found 325.1834. $\mathrm{C}_{21} \mathrm{H}_{24} \mathrm{O}_{3}$ requires 325.1804.

(E)-11/,13-dihydro-13-ethoxy-3-(phenylmethylene)-damsin (13).To a solution of 1 (100 mg, $0.4027 \mathrm{mmol})$ and benzaldehyde $(82.0 \mu \mathrm{L}, 0.8052 \mathrm{mmol})$ in EtOH $(1 \mathrm{~mL})$, was added TBAH $(265 \mu \mathrm{L}, 0.4027 \mathrm{mmol}$, solution $40 \%$ in water) and the reactionwas stirred at room temperature. After $24 \mathrm{~h}$, the reaction was acidified with a $10 \%$ $\mathrm{HCl}$ solution $(\mathrm{pH}=2)$, then brine $(15 \mathrm{~mL})$ was added and the aqueous mixture was extracted with DCM $(5 \times 20$ $\mathrm{mL}$ ). The combined organic layers were dried with $\mathrm{Na}_{2} \mathrm{SO}_{4}$ and concentrated in vacuo to give the crude product, which was purified by silicagel flash chromatography (from 20\% to 30\% EtOAc:Pet. Et.40-60) to provide the product 13 (77.2 mg, 50\%). $[\alpha]_{\mathbf{D}}{ }^{20}:+29.1\left(c 1.00, \mathrm{CH}_{2} \mathrm{Cl}_{2}\right)$; IR (film) $=2973,2927,2865,1763,1715,1624$, $1492,1449,1359,1251,1230,1182,1163,1108,1027,982,772,734,693,517 \mathrm{~cm}^{-1} ;\left(400 \mathrm{MHz} \mathrm{CDCl}_{3}\right) \delta 2.06$ (1H, $m, \mathrm{H}-1), \delta 2.84$ (1H, m, H-2a), $\delta 2.95\left(1 \mathrm{H}, d d d,{ }^{3} J 16.7 ; 12.3 ; 3.2 \mathrm{~Hz}, \mathrm{H}-2 \mathrm{~b}\right), \delta 4.61\left(1 \mathrm{H}, d,{ }^{3} J\right.$ 8.6 Hz, H-6), $\delta 2.79(1 \mathrm{H}, m, \mathrm{H}-7), \delta 1.71$ (1H, $m, \mathrm{H}-8 \mathrm{a}), \delta 1.97$ (1H, $m, \mathrm{H}-8 \mathrm{~b}), \delta 1.64$ (1H, $m, \mathrm{H}-9 \mathrm{a}), \delta 1.82(1 \mathrm{H}, m, \mathrm{H}-9 \mathrm{~b}), \delta$ $2.26(1 \mathrm{H}, m, \mathrm{H}-10), \delta 2.50\left(1 \mathrm{H}, d d d,{ }^{3} J\right.$ 7.2; $\left.5.2 ; 3.9 \mathrm{~Hz}, \mathrm{H}-11\right), \delta 3.67\left(1 \mathrm{H}, d d,{ }^{3} J\right.$ 9.6; $\left.3.8 \mathrm{~Hz}, \mathrm{H}-13 \mathrm{a}\right), \delta 3.70$ $\left(1 \mathrm{H}, d d,{ }^{3} J\right.$ 9.6; $\left.5.2 \mathrm{~Hz}, \mathrm{H}-13 \mathrm{~b}\right), \delta 1.16$ (3H, $\left.d,{ }^{3} J 7.1 \mathrm{~Hz}, \mathrm{Me}-14\right), \delta 1.20$ (3H, s, Me-15), $\delta 7.41$ (1H, $m, \mathrm{H}-1$ '),$\delta$ 7.54 (2H, $m, \mathrm{H}-2$ '”/6' '), $\delta 7.41$ (2H, $m, \mathrm{H}-3$ '”/5'), $\delta 7.35$ (1H, $m, \mathrm{H}-4$ '”), $\delta 3.48\left(2 \mathrm{H}, m,-\mathrm{OCH}_{2} \mathrm{CH}_{3}\right), \delta 1.14(3 \mathrm{H}$, $t,{ }^{3} J$ 7.0; $\left.7.0 \mathrm{~Hz},-\mathrm{OCH}_{2} \mathrm{CH}_{3}\right) ; \mathrm{d}_{\mathrm{C}}\left(100.6 \mathrm{MHz}, \mathrm{CDCl}_{3}\right) 43.6$ (C-1), 31.2 (C-2), 133.5 (C-3), 208.0 (C-4), 54.6 (C-5), 82.8 (C-6), 43.7 (C-7), 25.6 (C-8), 34.3 (C-9), 34.0 (C-10), 48.8 (C-11), 177.1 (C-12), 68.7 (C-13), 15.8 (C-14), 14.7 (C-15), 133.7 (C-1'), 135.4 (C-1'’), 130.5 (C-2'’/6’'), 128.7 (C-3’'/5'), 129.4 (C-4'”), 66.8 $\left(-\mathrm{OCH}_{2} \mathrm{CH}_{3}\right), 14.9\left(-\mathrm{OCH}_{2} \mathrm{CH}_{3}\right)$; HRMS-ESI: [M+H $\left.{ }^{+}\right]$, found 383.2228. $\mathrm{C}_{24} \mathrm{H}_{30} \mathrm{O}_{4}$ requires 383.2222.

11/ק,13-epoxy-10-hydroxydamsin (14). Two stock solutions were prepared: I) $42 \mathrm{mg}$ of $\mathbf{1 6}$ and AcOH (35.0 $\mu \mathrm{L})$ in $\mathrm{ACN}(1.8 \mathrm{~mL})$. II) $99 \mu \mathrm{L}$ of $\mathrm{H}_{2} \mathrm{O}_{2} 50 \% \mathrm{wt}$ in ACN $(13.5 \mathrm{~mL})$. To a stirred solution of $100 \mathrm{mg}$ of $\mathbf{1}(0.4027$ mmol) in $0.6 \mathrm{~mL}$ of Stock I [Containing: 16 (14.0 mg, $0.0201 \mathrm{mmol})$, AcOH $(11.5 \mu \mathrm{L}, 0.2013 \mathrm{mmol})$ ], was added $4.5 \mathrm{~mL}$ of Stock II [Containing: $\mathrm{H}_{2} \mathrm{O}_{2} 50 \% \mathrm{wt}(33.0 \mu \mathrm{L}, 0.4832 \mathrm{mmol})$ ] dropwise during 5 minutes. The addition of the same amount of both Stock solutions was repeated two times more, with intervals of $20 \mathrm{~min}$ and following the same procedure. After the last addition, the reaction was stirred at room temperature for $2 \mathrm{~h}$. It was quenched with sat. $\mathrm{NaHCO}_{3}$ solution $(1 \mathrm{~mL})$ and the organic solvent was evaporated in vacuo. The remaining aqueous layer was extracted with EtOAc $(3 \times 20 \mathrm{~mL})$. The combined organic layers were dried with $\mathrm{Na}_{2} \mathrm{SO}_{4}$ and concentrated in vacuo to give the crude product, which was purified by silicagel flash chromatography (EtOAc) to provide the product 14 (44.0 mg, 39\%). $[\alpha]_{\mathbf{D}}{ }^{20}:-2.0\left(c 1.00, \mathrm{CH}_{2} \mathrm{Cl}_{2}\right)$; IR (film) = 3498, 2961, 2926, 2856, 1781, 1737, 1460, 1383, 1321, 1260, 1173, 1094, 1069, 1011, 978, 925, 873, 799, 734, 701, 623, 585, 527, 495, 449, $399 \mathrm{~cm}^{-1}$; (400 $\left.\mathrm{MHz} \mathrm{CDCl}_{3}\right) \delta 2.08\left(1 \mathrm{H}, d d,{ }^{3} J 12.7 ; 5.4 \mathrm{~Hz}, \mathrm{H}-1\right), \delta 1.81(1 \mathrm{H}, m, \mathrm{H}-2 \mathrm{a}), \delta 2.23(1 \mathrm{H}, m, \mathrm{H}-2 \mathrm{~b}), \delta 2.24(1 \mathrm{H}, m$, H-3a), $\delta 2.42$ (1H, $m, \mathrm{H}-3 \mathrm{~b}), \delta 4.69$ (1H, $\left.d,{ }^{3} J 9.3 \mathrm{~Hz}, \mathrm{H}-6\right), \delta 3.05$ (1H, $\left.m, \mathrm{H}-7\right), \delta 1.43(1 \mathrm{H}, m, \mathrm{H}-8 \mathrm{a}), \delta 1.83(1 \mathrm{H}$, $m, \mathrm{H}-8 \mathrm{~b}$ ), $\delta 1.57$ (1H, H-9a), $\delta 1.86$ (1H, H-9b), $\delta 3.06$ (1H, $\left.d,{ }^{3} J 5.5 \mathrm{~Hz}, \mathrm{H}-13 \mathrm{a}\right), \delta 3.15$ (1H, $\left.d,{ }^{3} J 5.7 \mathrm{~Hz}, \mathrm{H}-13 \mathrm{~b}\right)$, $\delta 1.25$ (3H, s, Me-14), $\delta 1.01$ (3H, s, Me-15); $\mathrm{d}_{\mathrm{C}}\left(100.6 \mathrm{MHz} \mathrm{CDCl}_{3}\right.$ ) 51.8 (C-1), 20.3 (C-2), 36.0 (C-3), 217.3 (C-4), 52.1 (C-5), 81.8 (C-6), 39.1 (C-7), 19.2 (C-8), 39.7 (C-9), 72.8 (C-10), 57.9 (C-11), 173.3 (C-12), 50.8 (C-13), 24.9 (C-14), 12.6 (C-15); HRMS-ESI: $\left[\mathrm{M}+\mathrm{H}^{+}\right]$, found 281.1402. $\mathrm{C}_{15} \mathrm{H}_{20} \mathrm{O}_{5}$ requires 281.1426.

epi-11,13-dihydro-13-( $N, N$-dimethylamino)damsin (15). To a solution of 1 (100 $\mathrm{mg}, 0.4027 \mathrm{mmol})$ in EtOH (5 mL)was added $\mathrm{Me}_{2} \mathrm{NH}(720 \mu \mathrm{L}, 4.0270 \mathrm{mmol}, 5.6 \mathrm{M}$ solution in EtOH) and the reaction was stirred at $0^{\circ} \mathrm{C}$. After $9 \mathrm{~h}$, the reaction was quenched evaporating the solvent in vacuo to give the crude product, which was not further purified. The product $15(114.3 \mathrm{mg}, 96 \%)$ was obtained as an unseparable mixture of epimers 3:1

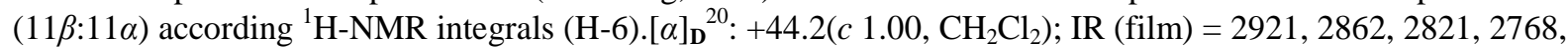
1759, 1736, 1459, 1408, 1382, 1347, 1316, 1268, 1224, 1175, 1154, 1127, 1088, 1051, 1030, 1007, 976, 953, 930, 845, 713, 684, 655, 627, $536 \mathrm{~cm}^{-1}$;11/,13-dihydro-13-( $\boldsymbol{N}, \boldsymbol{N}$-dimethylamino)damsin $\left(400 \mathrm{MHz} \mathrm{CDCl}_{3}\right) \delta$ $2.01(1 \mathrm{H}, m, \mathrm{H}-1), \delta 1.77$ (1H, $m, \mathrm{H}-2 \mathrm{a}), \delta 1.97(1 \mathrm{H}, m, \mathrm{H}-2 \mathrm{~b}), \delta 2.15(1 \mathrm{H}, m, \mathrm{H}-3 \mathrm{a}), \delta 2.37(1 \mathrm{H}, m, \mathrm{H}-3 \mathrm{~b}), \delta$ $4.41\left(1 \mathrm{H}, d,{ }^{3} J 8.4 \mathrm{~Hz}, \mathrm{H} 6\right), \delta 2.68(1 \mathrm{H}, m, \mathrm{H}-7), \delta 1.64(1 \mathrm{H}, m, \mathrm{H}-8 \mathrm{a}), \delta 1.87(1 \mathrm{H}, m, \mathrm{H}-8 \mathrm{~b}), \delta 1.65(1 \mathrm{H}, m$, H-9a), $\delta 1.65$ (1H, $m, \mathrm{H}-9 \mathrm{~b}), \delta 2.12(1 \mathrm{H}, m, \mathrm{H}-10), \delta 2.39$ (1H, $m, \mathrm{H}-11), \delta 2.48$ (2H, $m, \mathrm{H}-13 \mathrm{a}), \delta 1.02$ (3H, $d$, $\left.{ }^{3} J 7.5 \mathrm{~Hz}, \mathrm{Me}-14\right), \delta 1.07$ (3H, s, Me-15), $\delta 2.16$ (6H, s, H-16a); d $\mathrm{d}_{\mathrm{C}}\left(100.6 \mathrm{MHz}, \mathrm{CDCl}_{3}\right.$ ) 45.9, 23.7, 35.8, 219.3,

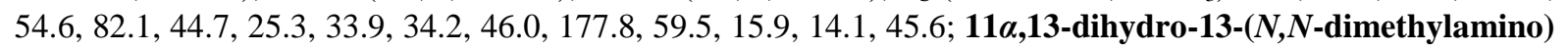
damsin $\left(400 \mathrm{MHz}^{2} \mathrm{CDCl}_{3}\right) \delta 2.01(1 \mathrm{H}, m, \mathrm{H}-1), \delta 1.77(1 \mathrm{H}, m, \mathrm{H}-2 \mathrm{a}), \delta 1.97(1 \mathrm{H}, m, \mathrm{H}-2 \mathrm{~b}), \delta 2.10(1 \mathrm{H}, m$, H-3a), $\delta 2.39$ (1H, $m, \mathrm{H}-3 \mathrm{~b}), \delta 4.46\left(1 \mathrm{H}, d,{ }^{3} J 5.4 \mathrm{~Hz}, \mathrm{H} 6\right), \delta 2.53(1 \mathrm{H}, m, \mathrm{H}-7), \delta 1.44$ (1H, $\left.m, \mathrm{H}-8 \mathrm{a}\right), \delta 1.60(1 \mathrm{H}$, 
$m$, H-8b), $\delta 1.57$ (1H, $m, \mathrm{H}-9 \mathrm{a}), \delta 1.79$ (1H, $m, \mathrm{H}-9 \mathrm{~b}), \delta 2.12$ (1H, $m, \mathrm{H}-10), \delta 2.83$ (1H, $m, \mathrm{H}-11), \delta 2.48$ (2H, $m$, H-13a), $\delta 1.02$ (3H, $d,{ }^{3} J 7.5 \mathrm{~Hz}, \mathrm{Me}-14$ ), $\delta 1.10$ (3H, s, Me-15), $\delta 2.17$ (6H, s, H-16a); $\mathrm{d}_{\mathrm{C}}\left(100.6 \mathrm{MHz}, \mathrm{CDCl}_{3}\right)$ 45.7, 23.9, 34.6, 219.3, 54.6, 81.7, 45.5, 17.8, 36.9, 34.8, 43.3, 176.8, 54.5, 16.5, 15.7, 45.3; HRMS-ESI: $\left[\mathrm{M}+\mathrm{H}^{+}\right]$, found 294.2070. $\mathrm{C}_{17} \mathrm{H}_{27} \mathrm{NO}_{3}$ requires 294.2069.

b) Biological assays

Cells and luciferase assays. The 5.1 clone line is a Jurkat derived clone stably transfected with a plasmid containing the luciferase gene driven by the HIV-LTR promoter were grown at $37^{\circ} \mathrm{C}$ and $5 \% \mathrm{CO}_{2}$ in supplemented RPMI 1640 containing 10\% heat-inactivated fetal bovine serum, $2 \mathrm{mM}$ glutamine, penicillin $(50 \mathrm{U} / \mathrm{mL})$ and streptomycin $(50 \mu \mathrm{g} / \mathrm{mL})$ and supplemented with G418 $(200 \mu \mathrm{g} / \mathrm{m})$. For the anti-NF- $\kappa B$ activity 5.1 cells were stimulated with TNF $\alpha(20 \mathrm{ng} / \mathrm{mL})$ in the presence or the absence of the compounds for six h. The cells were washed twice in PBS and lysed in $25 \mathrm{mM}$ Tris-phosphate $\mathrm{pH}$ 7.8, $8 \mathrm{mM} \mathrm{MgCl}, 1 \mathrm{mM} \mathrm{DTT}, 1 \%$ Triton X-100 and 7\% glycerol during $15 \mathrm{~min}$ at RT in a horizontal shaker. After centrifugation, the supernatant was used to measure luciferase activity using an Autolumat LB 9510 (Berthold) following the instructions of the luciferase assay kit (Promega, Madison, WI, USA).

c) Computational

Conformational search calculations for structural elucidation of all the molecules were performed with MacroModel (version 9.9, Schrödinger, LLC, New York, NY, 2011) using the force-field MMFFs, which was generated different conformers for each of molecule. The minimum energy conformer was chosen for full geometry optimization using the ab initio calculations with the basis set B3LYP/6-31G** (Jaguar, version 7.8, Schrödinger, LLC, New York, NY, 2011). The resulting geometries were used for subsequent comparison with the experimental NMR data.

\section{References}

[1] Li, Q. and Verma, I.M. (2002) NF-кB Regulation in the Immune System. Nature Reviews Immunology, 2, $725-734$. http://dx.doi.org/10.1038/nri910

[2] Gilmore, T.D. (2006) Introduction to NF-кB: Players, Pathways, Perspectives. Oncogene, 25, 6680-6684. http://dx.doi.org/10.1038/sj.onc.1209954

[3] Hayden, M.S. and Ghosh, S. (2008) Shared Principles in NF-kB Signaling. Cell, 132, 344-362. http://dx.doi.org/10.1016/j.cell.2008.01.020

[4] Ben-Neriah, Y. and Karin, M. (2011) Inflammation Meets Cancer, with NF- $\mathrm{B}$ as the Matchmaker. Nature Immunology, 12, 715-723. http://dx.doi.org/10.1038/ni.2060

[5] Karin, M. (2006) NF-кB and Cancer: Mechanisms and Targets. Molecular Carcinogenesis, 45, 355-361. http://dx.doi.org/10.1002/mc.20217

[6] Nakanishi, C. and Toi, M. (2005) Nuclear Factor-кB Inhibitors as Sensitizers to Anticancer Drugs. Nature Reviews Cancer, 5, 297-309. http://dx.doi.org/10.1038/nrc1588

[7] Kim, H.J., Hawke, N. and Baldwin, A.S. (2006) NF-кB and IKK as Therapeutic Targets in Cancer. Cell Death and Differentiation, 13, 738-747. http://dx.doi.org/10.1038/sj.cdd.4401877

[8] Orlowski, R.Z. and Baldwin Jr., A.S. (2002) NF-кB as a Therapeutic Target in Cancer. Trends in Molecular Medicine, 8, 385-389. http://dx.doi.org/10.1016/S1471-4914(02)02375-4

[9] Yamamoto, Y. and Gaynor, R.B. (2001) Therapeutic Potential of Inhibition of the NF- $\kappa$ B Pathway in the Treatment of Inflammation and Cancer. The Journal of Clinical Investigation, 107, 135-142. http://dx.doi.org/10.1172/JCI11914

[10] Brown, R.E., Tan, D., Taylor, J.S., Miller, M., Prichard, J.W. and Kott, M.M. (2007) Morphoproteomic Confirmation of Constitutively Activated mTOR, ERK, and NF-кB Pathways in High Risk Neuro-Blastoma, with Cell Cycle and Protein Analyte Correlates. Annals of Clinical \& Laboratory Science, 37, 141-147.

[11] Bours, V., Bentires-Alj, M., Hellin, A.C., Viatour, P., Robe, P., Delhalle, S., Benoit, V. and Merville, M.P. (2000)

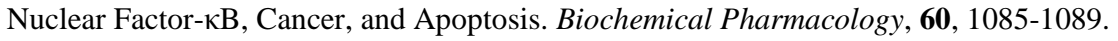
http://dx.doi.org/10.1016/S0006-2952(00)00391-9

[12] Baldwin, A.S. (2001) Control of Oncogenesis and Cancer Therapy Resistance by the Transcription Factor NF- $\kappa$ B. Journal of Clinical Investigation, 107, 241-246. http://dx.doi.org/10.1172/JCI11991

[13] Dolcet, X., Llobet, D., Pallares, J. and Matias-Guiu, X. (2005) NF-кB in Development and Progression of Human Cancer. Virchows Archiv, 446, 475-482. http://dx.doi.org/10.1007/s00428-005-1264-9

[14] Karin, M., Cao, Y., Greten, F.R. and Li, Z.W. (2002) NF-кB in Cancer: From Innocent Bystander to Major Culprit. Nature Reviews Cancer, 2, 301-310. http://dx.doi.org/10.1038/nrc780 
[15] Pacifico, F. and Leonardi, A. (2006) NF-kB in Solid Tumors. Biochemical Pharmacology, 72, 1142-1152. http://dx.doi.org/10.1016/j.bcp.2006.07.032

[16] Verma, I.M. (2004) Nuclear Factor (NF)-кB Proteins: Therapeutic Targets. Annals of the Rheumatic Diseases, 63, ii57ii61. http://dx.doi.org/10.1136/ard.2004.028266

[17] Picman, A.K. (1986) Biological Activities of Sesquiterpene Lactones. Biochemical Systematics and Ecology, 14, 255-281. http://dx.doi.org/10.1016/0305-1978(86)90101-8

[18] Ghantous, A., Gali-Muhtasib, H., Vuorela, H., Saliba, N.A. and Darwiche, N. (2010) What Made Sesquiterpene Lactones Reach Cancer Clinical Trials? Drug Discovery Today, 15, 668-678. http://dx.doi.org/10.1016/j.drudis.2010.06.002

[19] Zhang, S., Won, Y.K., Ong, C.N. and Shen, H.M. (2005) Anti-Cancer Potential of Sesquiterpene Lactones: Bioactivity and Molecular Mechanisms. Current Medicinal Chemistry-Anti-Cancer Agents, 5, 239-249. http://dx.doi.org/10.2174/1568011053765976

[20] Salminen, A., Lehtonen, M., Suuronen, T., Kaarniranta, K. and Huuskonen, J. (2008) Terpenoids: Natural Inhibitors of NF-кB Signaling with Anti-Inflammatory and Anticancer Potential. Cellular and Molecular Life Sciences, 65, 29792999. http://dx.doi.org/10.1007/s00018-008-8103-5

[21] Kreuger, M.R., Grootjans, S., Biavatti, M.W., Vandenabeele, P. and D’Herde, K. (2012) Sesquiterpene Lactones as Drugs with Multiple Targets in Cancer Treatment: Focus on Parthenolide. Anti-Cancer Drugs, 23, 883-896.

[22] Scotti, M.T., Fernandes, M.B., Ferreira, M.J.P. and Emerenciano, V.P. (2007) Quantitative Structure-Activity Relationship of Sesquiterpene Lactones with Cytotoxic Activity. Bioorganic \& Medicinal Chemistry, 15, 2927-2934. http://dx.doi.org/10.1016/j.bmc.2007.02.005

[23] Siedle, B., García-Piñeres, A.J., Murillo, R., Schulte-Mönting, J., Castro, V., Rüngeler, P., Klaas, C.A., Da Costa, F.B., Kisiel, W. and Merfort, I. (2004) Quantitative Structure-Activity Relationship of Sesquiterpene Lactones as Inhibitors of the Transcription Factor NF-kB. Journal of Medicinal Chemistry, 47, 6042-6054. http://dx.doi.org/10.1021/jm049937r

[24] Fernandes, M.B., Scotti, M.T., Ferreira, M.J.P. and Emerenciano, V.P. (2008) Use of Self-Organizing Maps and Molecular Descriptors to Predict the Cytotoxic Activity of Sesquiterpene Lactones. European Journal of Medicinal Chemistry, 43, 2197-2205. http://dx.doi.org/10.1016/j.ejmech.2008.01.003

[25] Schmidt, T.J. and Heilmann, J. (2002) Quantitative Structure-Cytotoxicity Relationships of Sesquiterpene Lactones Derived from Partial Charge (q)-Based Fractional Accessible Surface Area Descriptors (Q_frASAs). Quantitative Structure-Activity Relationships, 21, 277-287. http://dx.doi.org/10.1002/1521-3838(200208)21:3<276::AID-QSAR276>3.0.CO;2-S

[26] Kupchan, S.M., Fessler, D.C., Eakin, M.A. and Giacobbe, T.J. (1970) Reactions of Alpha Methylene Lactone Tumor Inhibitors with Model Biological Nucelophiles. Science, 168, 376-378. http://dx.doi.org/10.1126/science.168.3929.376

[27] Perkins, N.D. (2012) Cysteine 38 Holds the Key to NF- $\kappa B$ Activation. Molecular Cell, 45, 1-3. http://dx.doi.org/10.1016/j.molcel.2011.12.023

[28] Rüngeler, P., Castro, V., Mora, G., Gören, N., Vichnewski, W., Pahl, H.L., Merfort, I. and Schmidt, T.J. (1999) Inhibition of Transcription Factor NF- $\kappa$ B by Sesquiterpene Lactones: A Proposed Molecular Mechanism of Action. Bioorganic \& Medicinal Chemistry, 7, 2343-2352. http://dx.doi.org/10.1016/S0968-0896(99)00195-9

[29] Garcia-Pineres, A.J., Castro, V., Mora, G., Schmidt, T.J., Strunck, E., Pahl, H.L. and Merfort, I. (2001) Cysteine 38 in p65/NF-кB Plays a Crucial Role in DNA Binding Inhibition by Sesquiterpene Lactones. Journal of Biological Chemistry, 276, 39713-39720. http://dx.doi.org/10.1074/jbc.M101985200

[30] Garcia-Pineres, A.J., Lindenmeyer, M.T. and Merfort, I. (2004) Role of Cysteine Residues of p65/NF- $\kappa$ B on the Inhibition by the Sesquiterpene Lactone Parthenolide and N-Ethyl Maleimide, and on Its Transactivating Potential. Life Sciences, 75, 841-856. http://dx.doi.org/10.1016/j.lfs.2004.01.024

[31] Penarrieta, J.M., Soruco, M.L., Flores, Y. and Almanza, G.R. (2003) High Yield of Damsin, a Sesquiterpene with Antineoplasic Activity, in the Plant Species Franseria Artemisioides. Revista Boliviana de Química, 20, 32-36.

[32] Lee, K.H., Huang, E.S., Piantadosi, C., Pagano, J.S. and Geissman, T.A. (1971) Cytotoxicity of Sesquiterpene Lactones. Cancer Research, 31, 1649-1654.

[33] Doskotch, R.W. and Hufford, C.D. (1969) Damsin, the Cytotoxic Principle of Ambrosia Ambrosioides (Cav.) Payne. Journal of Pharmaceutical Sciences, 58, 186-188. http://dx.doi.org/10.1002/jps.2600580208

[34] De Leo, M., Saltos, M.B.V., Puente, B.F.N., De Tommasi, N. and Braca, A. (2010) Sesquiterpenes and Diterpenes from Ambrosia Arborescens. Phytochemistry, 71, 804-809. http://dx.doi.org/10.1016/j.phytochem.2010.02.002

[35] Villagomez, R., Rodrigo, G.C., Collado, I.G., Calzado, M.A., Muñoz, E., Åkesson, B., Sterner, O., Almanza, G.R. and Duan, R.D. (2013) Multiple Anticancer Effects of Damsin and Coronopilin Isolated from Ambrosia Arborescens on 
Cell Cultures. Anticancer Research, 33, 3799-3805.

[36] Herz, W., Anderson, G., Gibaja, S. and Raulais, D. (1969) Sesquiterpene Lactones of Some Ambrosia Species. Phytochemistry, 8, 877-881. http://dx.doi.org/10.1016/S0031-9422(00)85877-X

[37] Romo, J., Joseph-Nathan, P. and Díaz, F.A. (1964) The Constituents of Helenium aromaticum (Hook) Bailey: The Structures of Aromatin and Aromaticin. Tetrahedron, 20, 79-85. http://dx.doi.org/10.1016/S0040-4020(01)98399-1

[38] Shah, B.A., Taneja, S.C., Sethi, V.K., Gupta, P., Andotra, S.S., Chimni, S.S. and Qazi, G.N. (2007) The Formation of Novel 1,3-Dioxolanes: Atypical Baylis-Hillman Reaction of a Sesquiterpene Lactone Parthenin. Tetrahedron Letters, 48, 955-960. http://dx.doi.org/10.1016/j.tetlet.2006.12.019

[39] Shah, B.A., Kaur, R., Gupta, P., Kumar, A., Sethi, V.K., Andotra, S.S., Singh, J., Saxena, A.K. and Taneja, S.C. (2009) Structure-Activity Relationship (SAR) of Parthenin Analogues with Proapoptotic Activity: Development of Novel Anti-Cancer Leads. Bioorganic \& Medicinal Chemistry Letters, 19, 4394-4398. http://dx.doi.org/10.1016/j.bmcl.2009.05.089

[40] Hejchman, E., Haugwitz, R.D. and Cushman, M. (1995) Synthesis and Cytotoxicity of Water-Soluble Ambrosin Prodrug Candidates. Journal of Medicinal Chemistry, 38, 3407-3410. http://dx.doi.org/10.1021/jm00017a025

[41] Hooper, M., Kirby, G.C., Kulkarni, M.M., Kulkarni, S.N., Nagasampagi, B.A., O’Neill, M.J., Phillipson, J.D., Rojatkar, S.R. and Warhurst, D.C. (1990) Antimalarial Activity of Parthenin and Its Derivatives. European Journal of Medicinal Chemistry, 25, 717-723. http://dx.doi.org/10.1016/0223-5234(90)90190-E

[42] Villagomez, R., Quiroz, M., Tito, A., Sterner, O. and Almanza, G.R. (2014) Natural Pseudoguaianolides Prepared from Damsin. Chem Nat Comp, submitted.

[43] Gemal, A.L. and Luche, J.L. (1981) Lanthanoids in Organic Synthesis. 6. Reduction of $\alpha$-enones by Sodium Borohydride in the Presence of Lanthanoid Chlorides: Synthetic and Mechanistic Aspects. Journal of the American Chemical Society, 103, 5454-5459. http://dx.doi.org/10.1021/ja00408a029

[44] Wissner, A., Overbeek, E., Reich, M.F., Floyd, M.B., Johnson, B.D., Mamuya, N., Rosfjord, E.C., Discafani, C., Davis, R., Shi, X., Rabindran, S.K., Gruber, B.C., Ye, F., Hallett, W.A., Nilakantan, R., Shen, R., Wang, Y.-F., Greenberger, L.M. and Tsou, H.R. (2002) Synthesis and Structure-Activity Relationships of 6,7-Disubstituted 4-Anilinoquinoline-3Carbonitriles. The Design of an Orally Active, Irreversible Inhibitor of the Tyrosine Kinase Activity of the Epidermal Growth Factor Receptor (EGFR) and the Human Epidermal Growth Factor Receptor-2 (HER-2). Journal of Medicinal Chemistry, 46, 49-63. http://dx.doi.org/10.1021/jm020241c

[45] Bagal, S.K., Adlington, R.M., Brown, R.A.B. and Baldwin, J.E. (2005) Regioselectivity of Dimerisation of Butenolides via Captodative Stabilised Radicaloid Intermediates. Tetrahedron Letters, 46, 4633-4637. http://dx.doi.org/10.1016/j.tetlet.2005.04.125

[46] Han, C., Barrios, F.J., Riofski, M.V. and Colby, D.A. (2009) Semisynthetic Derivatives of Sesquiterpene Lactones by Palladium-Catalyzed Arylation of the $\alpha$-Methylene- $\gamma$-lactone Substructure. Journal of Organic Chemistry, 74, 71767179. http://dx.doi.org/10.1021/jo901533e

[47] Belovodskii, A.V., Shul’ts, E.E., Shakirov, M.M. and Tolstikov, G.A. (2009) Sesquiterpene Metylenelactones in a Palladium-Catalyzed Cross-Coupling Reaction. Doklady Chemistry, 426, 138-142. http://dx.doi.org/10.1134/S001250080906007X

[48] Rosamilia, A.E., Giarrusso, M.A., Scott, J.L. and Strauss, C.R. (2006) A Direct, Efficient Synthesis of Unsymmetrically Substituted bis(arylidene)alkanones. Green Chemistry, 8, 1042-1050. http://dx.doi.org/10.1039/b606042k

[49] Chen, M.S. and White, M.C. (2007) A Predictably Selective Aliphatic C-H Oxidation Reaction for Complex Molecule Synthesis. Science, 318, 783-787. http://dx.doi.org/10.1126/science.1148597

[50] Lee, K.H., Furukawa, H. and Huang, E.S. (1972) Antitumor Agents. 3. Synthesis and Cytotoxic Activity of Helenalin Amine Adducts and Related Derivatives. Journal of Medicinal Chemistry, 15, 609-611. http://dx.doi.org/10.1021/jm00276a010

[51] Muñoz, E., Blazquez, M.V., Ortiz, C., Gomez-Diaz, C. and Navas, P. (1997) Role of Ascorbate in the Activation of NF- $\kappa B$ by Tumour Necrosis Factor-Alpha in T-Cells. Biochemical Journal, 325, 23-28.

[52] Castro, V., Rüngeler, P., Murillo, R., Hernandez, E., Mora, G., Pahl, H.L. and Merfort, I. (2000) Study of Sesquiterpene Lactones from Milleria quinqueflora on Their Anti-Inflammatory Activity Using the Transcription Factor NF- $\kappa \mathrm{B}$ as Molecular Target. Phytochemistry, 53, 257-263. http://dx.doi.org/10.1016/S0031-9422(99)00510-5

[53] Kupchan, S.M., Giacobbe, T.J., Krull, I.S., Thomas, S.M., Eakin, M.A. and Fessler, D.C. (1970) Tumor Inhibitors. LVII. Reaction of Endocyclic .Alpha.,.Beta.-Unsaturated .Gamma.-Lactones with Thiols. Journal of Organic Chemistry, 35, 3539-3543. http://dx.doi.org/10.1021/jo00835a078 
Scientific Research Publishing (SCIRP) is one of the largest Open Access journal publishers. It is currently publishing more than 200 open access, online, peer-reviewed journals covering a wide range of academic disciplines. SCIRP serves the worldwide academic communities and contributes to the progress and application of science with its publication.

Other selected journals from SCIRP are listed as below. Submit your manuscript to us via either submit@scirp.org or Online Submission Portal.
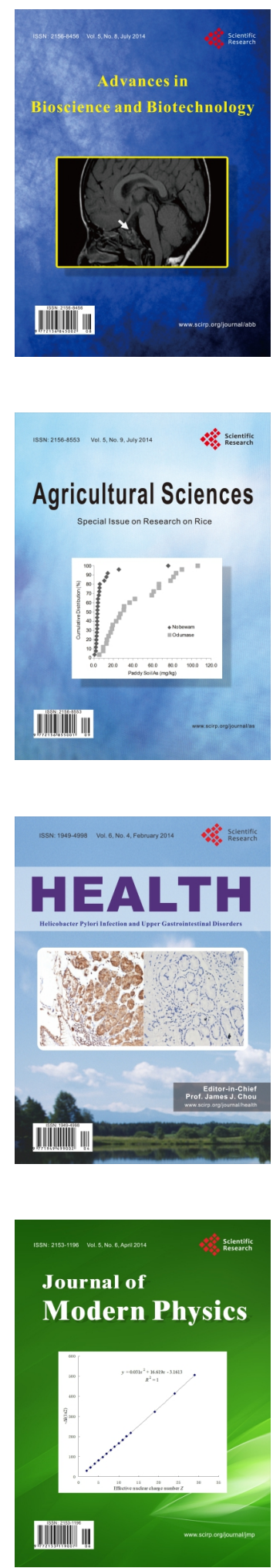
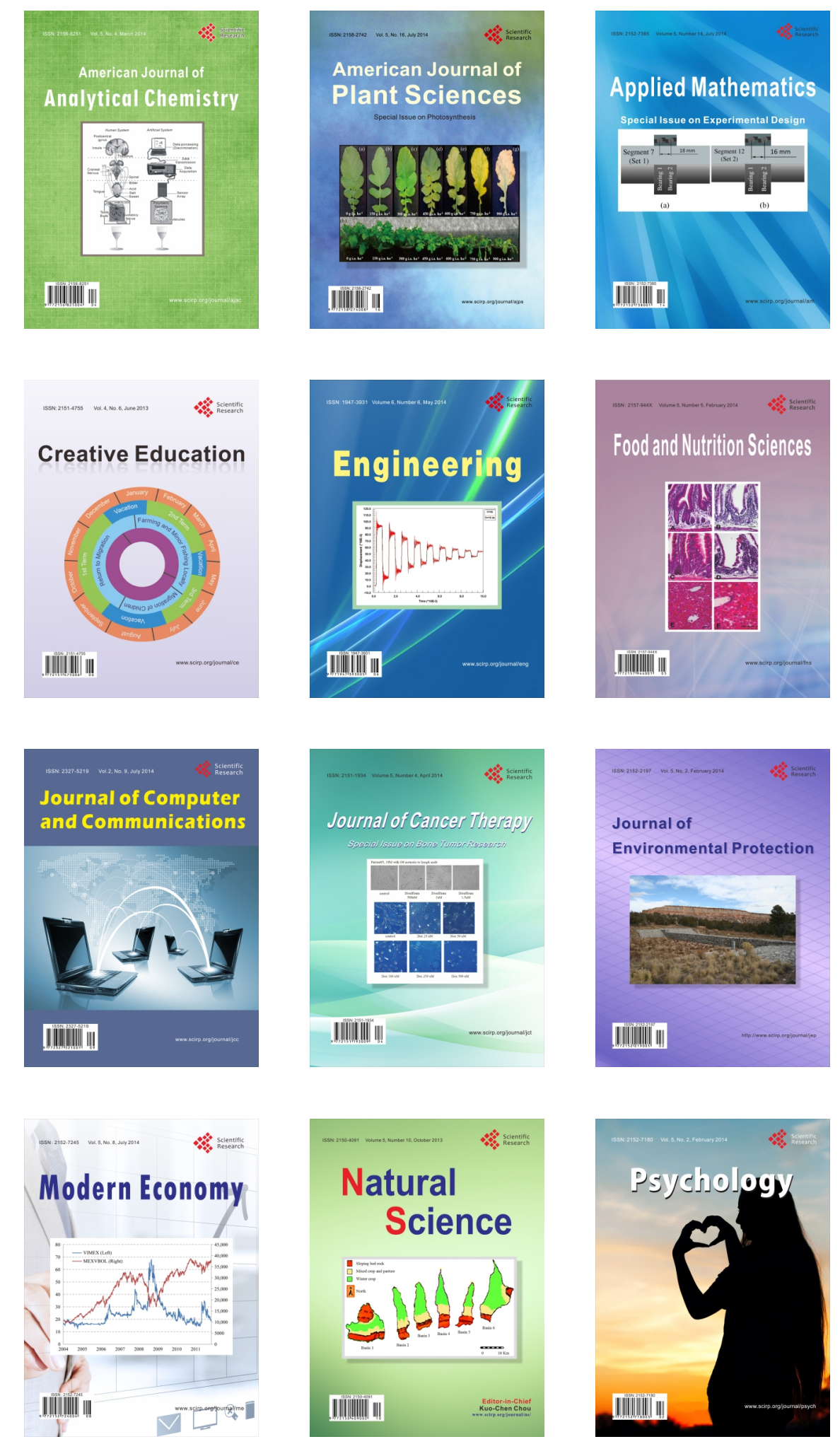